\title{
Carbonyl sulfide exchange in soils for better estimates of ecosystem carbon uptake
}

\author{
Mary E. Whelan ${ }^{1,2}$, Timothy W. Hilton ${ }^{1}$, Joseph A. Berry ${ }^{2}$, Max Berkelhammer ${ }^{3}$, Ankur R. Desai ${ }^{4}$, and \\ J. Elliott Campbell ${ }^{1}$ \\ ${ }^{1}$ Department of Environmental Engineering, University of California, Merced, Merced, CA, USA \\ ${ }^{2}$ Carnegie Institution for Science, Stanford, CA, USA \\ ${ }^{3}$ Department of Earth and Environmental Sciences, University of Illinois Chicago, Chicago, IL, USA \\ ${ }^{4}$ Department of Atmospheric and Oceanic Sciences, University of Wisconsin, Madison, WI, USA \\ Correspondence to: M. E. Whelan (marywhelan@gmail.com)
}

Received: 7 June 2015 - Published in Atmos. Chem. Phys. Discuss.: 6 August 2015

Revised: 23 February 2016 - Accepted: 25 February 2016 - Published: 21 March 2016

\begin{abstract}
Carbonyl sulfide (COS) measurements are one of the emerging tools to better quantify gross primary production (GPP), the largest flux in the global carbon cycle. COS is a gas with a similar structure to $\mathrm{CO}_{2}$; $\mathrm{COS}$ uptake is thought to be a proxy for GPP. However, soils are a potential source or sink of COS. This study presents a framework for understanding soil-COS interactions. Excluding wetlands, most of the few observations of isolated soils that have been made show small uptake of atmospheric COS. Recently, a series of studies at an agricultural site in the central United States found soil COS production under hot conditions an order of magnitude greater than fluxes at other sites. To investigate the extent of this phenomenon, soils were collected from five new sites and incubated in a variety of soil moisture and temperature states. We found that soils from a desert, an oak savannah, a deciduous forest, and a rainforest exhibited small COS fluxes, behavior resembling previous studies. However, soil from an agricultural site in Illinois, $>800 \mathrm{~km}$ away from the initial central US study site, demonstrated comparably large soil fluxes under similar conditions. These new data suggest that, for the most part, soil COS interaction is negligible compared to plant uptake of COS. We present a model that anticipates the large agricultural soil fluxes so that they may be taken into account. While COS air-monitoring data are consistent with the dominance of plant uptake, improved interpretation of these data should incorporate the soil flux parameterizations suggested here.
\end{abstract}

\section{Introduction}

As anthropogenic $\mathrm{CO}_{2}$ emissions continue increasing, it is necessary to characterize the partitioning of carbon exchange between atmospheric and terrestrial ecosystem reservoirs to predict future $\mathrm{CO}_{2}$ concentrations in the atmosphere (Wofsy, 2001). Large uncertainties remain in estimates of the amount of carbon removed from the atmosphere by photosynthesis (Beer et al., 2010), called gross primary productivity (GPP). This quantity is essential for describing carbon-climate feedbacks and assessing ecosystem-based $\mathrm{CO}_{2}$ capture and storage projects. Using measurements of carbonyl sulfide is one of several emerging approaches to address large uncertainties in GPP estimates (Berry et al., 2013; Campbell et al., 2008; Commane et al., 2013; Montzka et al., 2007; SandovalSoto et al., 2005; Seibt et al., 2010; Stimler et al., 2011; Suntharalingam et al., 2008). With a globally averaged tropospheric mixing ratio of $500 \pm 100$ parts per trillion (ppt) (Montzka et al., 2007), COS is the most abundant sulfurcontaining gas in Earth's atmosphere. Both $\mathrm{COS}$ and $\mathrm{CO}_{2}$ enter a plant through leaf stomata. Whereas some $\mathrm{CO}_{2}$ is released again in back-diffusion or in respiration, COS is irreversibly destroyed by carbonic anhydrase (ProtoschillKrebs et al., 1996; Schenk et al., 2004). Other enzymes such as RuBisCO can also destroy COS (Protoschill-Krebs and Kesselmeier, 1992). In soils, algal populations are expected to be smaller than bacterial populations (Wingate et al., 2009), and COS uptake is generally attributed to carbonic anhydrase. Soil COS fluxes potentially introduce large 
uncertainties in estimating the COS leaf uptake flux from atmospheric COS measurements (Maseyk et al., 2014).

To date only three published studies have attempted to use COS concentrations to calculate GPP over individual ecosystems (Asaf et al., 2013; Billesbach et al., 2014; Blonquist et al., 2011). The calculation is performed using this relationship:

$$
F_{\mathrm{COS}, \text { leaf }}=\mathrm{GPP}[\mathrm{COS}]\left[\mathrm{CO}_{2}\right]^{-1} v(p, i, w),
$$

$F_{\mathrm{COS} \text {,leaf }}$ is the one-way flux of $\mathrm{COS}$ into plant leaves in pmol m${ }^{-2} \mathrm{~s}^{-1}$, GPP is the $\mathrm{CO}_{2}$ assimilation by plants in $\mu \mathrm{mol} \mathrm{m} \mathrm{m}^{-2} \mathrm{~s}^{-1}$, [COS] and $\left[\mathrm{CO}_{2}\right]$ are ambient gas mixing ratios in parts per trillion (ppt) and parts per million (ppm), respectively, and the factor $v$ is the experimentally determined ratio of deposition velocities for $\mathrm{COS}$ and $\mathrm{CO}_{2}$, a function of plant type $p$, radiation $i$, and water stress $w$.

Many of the plant physiological requirements involved in using COS fluxes as a GPP proxy have been empirically investigated. Stimler et al. (2010) confirmed the assumptions about in-leaf processes and COS- $\mathrm{CO}_{2}$ exchange that need to be met to use COS as a tracer for GPP - i.e., COS codiffuses with $\mathrm{CO}_{2}$ via the same pathway in plant leaves, $\mathrm{COS}$ and $\mathrm{CO}_{2}$ do not inhibit one another at reaction sites with carbonic anhydrase, and emission of COS by leaves is negligible. However, other studies have found species-specific COS emissions by plants (Geng and Mu, 2006; Whelan et al., 2013). For the most part, using COS to predict GPP at the leaf level was comparable to other methods like $\mathrm{C}^{18} \mathrm{OO}$ exchange (Seibt et al., 2010; Stimler et al., 2011).

However, a problem arises when the $\operatorname{COS~:~} \mathrm{CO}_{2}$ scheme is applied to an ecosystem beyond the leaf scale. The uptake ratio is called an ecosystem relative uptake (ERU) when the observation scale encompasses plants and soils (Campbell et al., 2008) or a soil relative uptake (SRU) when soils are observed or modeled apart from plant systems (Berkelhammer et al., 2014). Empirical measurements of ERU deviate from the value of 3 (Sandoval-Soto et al., 2005) when processes other than photosynthesis dominate trace gas exchange over an ecosystem (Seibt et al., 2010). In these cases, it is assumed that a missing source or sink of $\mathrm{COS}$ or $\mathrm{CO}_{2}$ exchange is present in the system. At continental scales, anthropogenic sources must be taken into account (Campbell et al., 2015). In many natural ecosystems, COS exchange by soils contributes to variations in ERU.

Soils in terrestrial biomes usually exhibit low COS exchanges compared to uptake by plants (see review in Whelan et al., 2013). Uncoordinated, individual studies have been undertaken that incidentally quantified soil COS exchange in a limited number of biomes, often with few soil-focused measurements.

The characterization of soil COS exchange should improve the use of COS observations as a GPP proxy. Here, to better understand soil COS exchange, we collected soil samples from multiple biomes and assessed their COS fluxes in a controlled setting using dynamic incubation chambers. We further develop a framework for interpreting and anticipating soil COS fluxes based on empirical data and gas exchange theory. This model can inform the design of much needed future field experiments.

\section{Methods}

Soil samples were acquired from agricultural, forest, desert, and savannah sites (Table 1) with a variety of patterns in soil moisture and temperature (Fig. 1). Except for the Peruvian rainforest sample, soil collection followed the same protocol. First, two $0.0225 \mathrm{~m}^{2}$ representative sites were selected, one adjacent to the biome's predominant vegetation, the other a meter away. The litter layer was removed and reserved separately. Soil was then excavated from the top $0.05 \mathrm{~m}$ of a $0.01 \mathrm{~m}^{2}$ area, double-bagged, and shipped overnight to the Carnegie Institution for Science in Stanford, CA, for analysis. The Peruvian rainforest sample was an amalgamation of soils from the top $0.05 \mathrm{~m}$ of several sites, collected by auger from the Los Amigos Biological Station in Peru. These soils were air-dried and then combined before analysis. Bulk density and soil moisture content for all soils were determined by gravimetric methods. Soil $\mathrm{pH}$ was measured with a Corning Pinnacle $530 \mathrm{pH}$ meter (Xylem Inc., White Plains, NY). Locations of sites are shown in Fig. 2.

Sites were selected to capture variability between biomes and address data needs. The Bondville site is an agricultural research station that was rotated between soybean and corn crops; at the time of sampling, soybeans were planted, but soil contained corn litter. The Stunt Ranch FLUXNET site, an oak savannah, and the Boyd Deep Canyon Reserve, to our knowledge the first desert soil investigated for COS exchange, are both located within and managed by the University of California Reserve System. The Willow Creek mature forest, Bondville FLUXNET, and Southern Great Plains ARM sites are within the footprints of COS air-monitoring sites that include tall tower and airborne platforms (Montzka et al., 2007). Soil temperature and soil moisture variability for all sites are presented in Fig. 1.

The experimental chambers were solid PFA $1 \mathrm{~L}$ jars and threaded solid PFA lids with two ports (Savillex, Eden Prairie, MN, USA). PTFE tape was used to achieve an airtight seal on the threads. The outlet port was attached to PFA tubing extending into the middle of the chamber. Soil subsamples were placed in individual chambers and weighed. Following Van Diest and Kesselmeier (2008), 75 to $80 \mathrm{~g}$ soil samples were used to reduce the presence of concentration gradients in the soil profile during dynamic incubation experiments. One soil subsample from the agricultural site was wet-filtered through a $53 \mu \mathrm{m}$ sieve to remove the sand-sized soil fraction before incubation. Otherwise, soils were not sieved; large pieces of loose litter were already removed when the soils were initially collected. By keeping soils whole, we reduced the influence of sample processing 
Table 1. Site descriptions for soils used in this study and soils from the site used in Billesbach et al. (2014) and Maseyk et al. (2014). Site descriptions for the FLUXNET sites can be found in Meyers and Hollinger (2004), Anderson and Goulden (2011), and Cook et al. (2004). The temperature and soil moisture ranges are the maximum and minimum of 10 years' worth of hourly data from the Climate Forecast System Reanalysis (CFSRv2; Saha et al., 2010).

\begin{tabular}{|c|c|c|c|c|c|c|c|c|}
\hline Site & Description & $\begin{array}{r}\text { Bulk } \\
\text { density }\end{array}$ & $\mathrm{pH}$ & $\begin{array}{r}\text { Site temperature } \\
\text { range at } 5 \mathrm{~cm}(\mathrm{C})\end{array}$ & $\begin{array}{r}\text { Soil moisture } \\
\text { range }(\% \mathrm{VWC})\end{array}$ & $\begin{array}{r}\text { Sand } \\
(\%)\end{array}$ & $\begin{array}{l}\text { Silt } \\
(\%)\end{array}$ & $\begin{array}{r}\text { Clay } \\
(\%)\end{array}$ \\
\hline $\begin{array}{l}\text { Stunt Ranch Reserve } \\
\left(34.0939^{\circ} \mathrm{N}, 118.6567^{\circ} \mathrm{W}\right)\end{array}$ & Oak savannah & 1.11 & 7.0 & $4.2-37$ & $13-45$ & 47 & 31 & 22 \\
\hline $\begin{array}{l}\text { Boyd Deep Canyon, US-SCd } \\
\left(33.6481^{\circ} \mathrm{N}, 116.3767^{\circ} \mathrm{W}\right)\end{array}$ & Colorado desert & 1.46 & 7.5 & $-0.23-44$ & $12-38$ & 86 & 7 & 7 \\
\hline $\begin{array}{l}\text { Willow Creek FLUXNET, US-WCr } \\
\left(45.8060^{\circ} \mathrm{N}, 90.0798^{\circ} \mathrm{W}\right)\end{array}$ & Deciduous forest & 0.84 & 5.8 & $-22-29$ & $9.5-42$ & 62 & 30 & 8 \\
\hline $\begin{array}{l}\text { Los Amigos Biological Station, Peru } \\
\left(12.5692^{\circ} \mathrm{S}, 70.1001^{\circ} \mathrm{W}\right)\end{array}$ & Rainforest & 0.92 & 3.9 & $14-31$ & $15-47$ & 63 & 21 & 16 \\
\hline $\begin{array}{l}\text { Bondville FLUXNET, US-Bo1 } \\
\left(40.0062^{\circ} \mathrm{N}, 88.2904^{\circ} \mathrm{W}\right)\end{array}$ & Soybean/corn & 1.09 & 6.1 & $-14-33$ & $12-46$ & 20 & 55 & 25 \\
\hline $\begin{array}{l}\text { Southern Great Plains ARM site, } \\
\text { site of previous studies } \\
\left(36.6050^{\circ} \mathrm{N}, 97.4850^{\circ} \mathrm{W}\right)\end{array}$ & Wheat field & 1.14 & 4.2 & $-7.8-40$ & $12-46$ & 15 & 63 & 22 \\
\hline
\end{tabular}

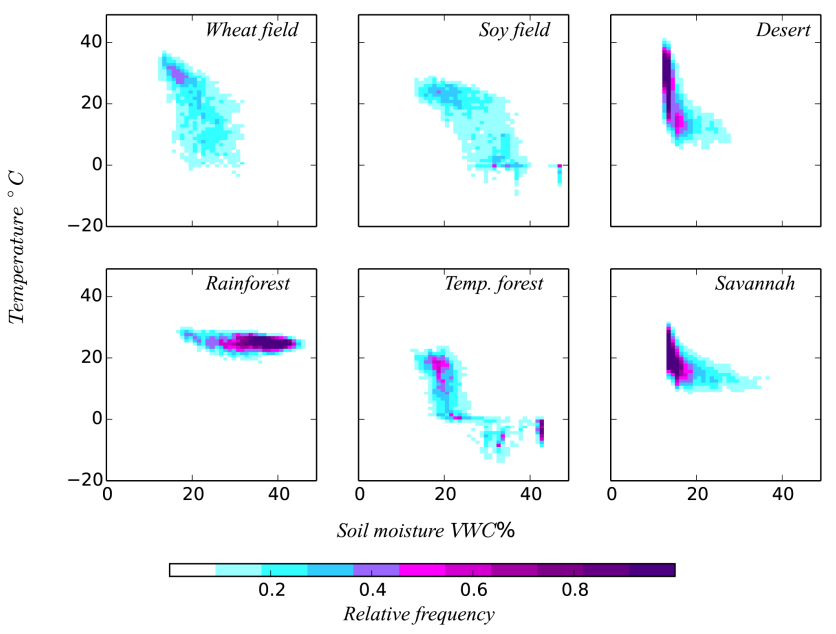

Figure 1. The normalized concurrence of soil moisture and $5 \mathrm{~cm}$ depth temperature at sites where soils were collected for this study and the wheat field where the Maseyk et al. (2014) study was performed, hourly Climate Forecast System Reanalysis (CFSRv2; Saha et al., 2010) data over 2000 through 2009 from the nearest appropriate data point.

artifacts on our lab-based flux observations at the expense of working with non-homogenized and therefore less reproducible subsamples.

\subsection{Determination of soil COS exchange}

Soil fluxes of COS were determined using a dynamic, flowthrough chamber approach. A commercially available Aerodyne quantum cascade laser (QCL, Aerodyne Research, Inc.,

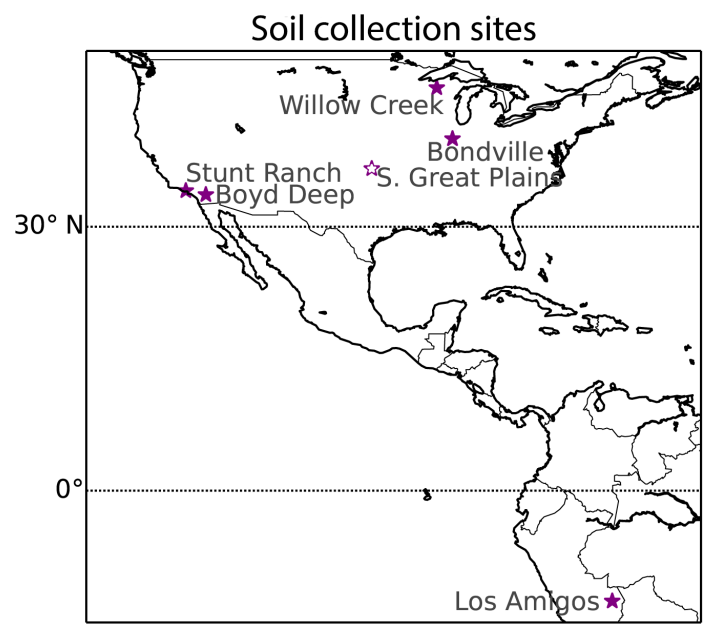

Figure 2. Locations of soil collection sites. The Southern Great Plains site is referred to in the discussion as the site used in Billesbach et al. (2014) and Maseyk et al. (2014), but was not used in these soil incubation experiments. For site descriptions, see Table 1.

Billerica, MA, US) was used to quantify $\mathrm{COS}$ and $\mathrm{CO}_{2}$ mixing ratios in the effluent of a laboratory-based apparatus (Fig. 3). The precision of the instrument was 8 ppt COS at $1 \mathrm{~Hz}$ and $2 \mathrm{ppt} \mathrm{COS}$ for observations averaged over $50 \mathrm{~s}$, with an absolute calibration accuracy of $5 \% \mathrm{COS}$ (Commane et al., 2013). Fluxes determined here required quantifying only relative mole ratios. Fluxes were calculated using an equation adapted from de Mello and Hines (1994): 


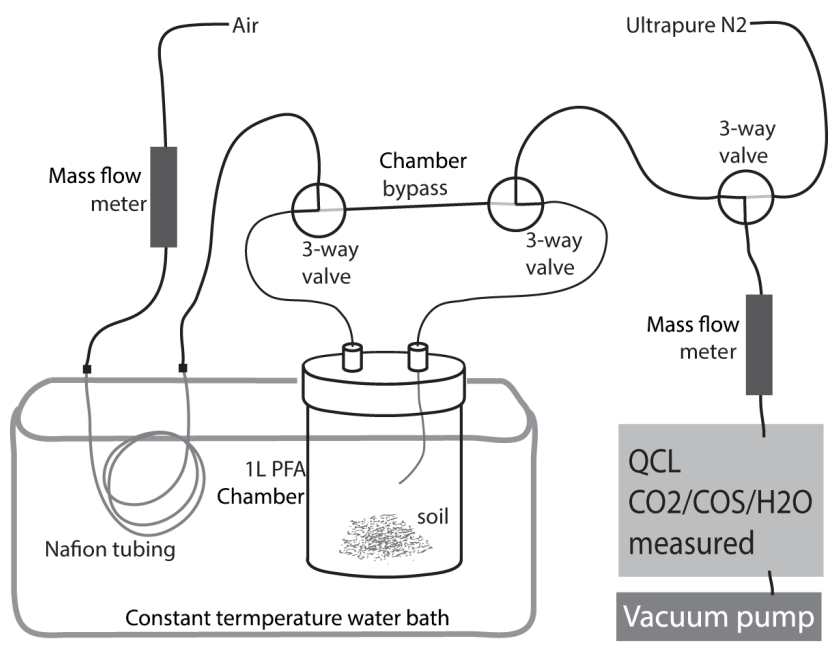

Figure 3. The experimental setup for laboratory-based soil incubation experiments. The Nafion tubing was placed in a container of water and used to humidify the incoming gas stream. Three-way valves were used to switch between analyzing a nitrogen stream, the gas stream that flowed through the chamber $\left(C_{f}\right.$, orientation of valves illustrated above), and the gas stream bypassing the chamber $\left(C_{i}\right)$.

$F=V\left(C_{f}-C_{i}\right) m_{\mathrm{soil}}^{-1}$

$F$ is the $\mathrm{COS}$ or $\mathrm{CO}_{2}$ exchange rate in pmol gas min ${ }^{-1} \mathrm{gdrys}^{-1}$. $C_{i}$ is the mixing ratio of the compound entering the chamber, determined by analyzing the gas stream bypassing the chamber headspace. $C_{f}$ is the mixing ratio of the compound exiting the $1 \mathrm{~L}$ PFA chamber headspace. $V$ represents the sweep rate of the total air through the chamber, measured by the mass flow meter upstream of the QCL, typically 0.29 to $0.31 \mathrm{Lmin}^{-1}$, and converted to pmol min ${ }^{-1}$. The value $m_{\text {soil }}$ is the amount of dry soil enclosed inside the chamber in grams. The flow of the system was driven by a vacuum pump downstream of the QCL. The instrument also measured $\mathrm{H}_{2} \mathrm{O}$ and applied an adjustment for dilution by water vapor, generally a less than $1 \%$ correction. According to the NIST spectral database, strong water vapor lines do not overlap the $\mathrm{COS}$ and $\mathrm{CO}_{2}$ lines at 2052.256 and $2052.096 \mathrm{~cm}^{-1}$. A more detailed description of the instrument can be found in Commane et al. (2013), with a further exploration of the instrument limitations by Kooijmans et al. (2016). Ambient laboratory air was used as the sweep gas for the incubations performed here. Observation of a dry nitrogen stream between incubations was used to correct for instrument baseline drift. While ambient COS mixing ratios had small variation $(510 \mathrm{ppt}$ with $80 \mathrm{ppt}$ standard deviation), some of the $\mathrm{CO}_{2}$ fluxes were uninterpretable because of variations in ambient $\mathrm{CO}_{2}$ mixing ratios, $C_{i}$. $\mathrm{CO}_{2}$ fluxes that could not be distinguished from 0 are graphically presented at 0 .

Each $F$ quantification is generated from $80 \mathrm{~min}$ of $1 \mathrm{~Hz}$ air analysis: $10 \mathrm{~min}$ of nitrogen gas, $10 \mathrm{~min}$ of bypass air, and $40 \mathrm{~min}$ of air directed through the soil chamber, followed by repeating the analysis of nitrogen gas and bypass air for $10 \mathrm{~min}$ each. To check for baseline stability, the ambient air and nitrogen gas were both analyzed for $10 \mathrm{~min}$ before and after each chamber measurement. Air flow was directed through the chamber and the effluent analyzed for $40 \mathrm{~min}$ to promote soil equilibration within a dynamic headspace. COS mole ratios were generated by monitoring the appropriate absorption lines. The average COS reported over the last several minutes of chamber flow-through and bypass were corrected for zero drift using the nitrogen (COS-free) signal, then used as $C_{f}$ and $C_{i}$, respectively, in Eq. (2). COS fluxes are reported in pmol COS per gram of dry weight soil per minute (pmol $\operatorname{COS} \mathrm{g}^{-1} \mathrm{~min}^{-1}$ ); negative values indicate uptake of COS, when $C_{f}<C_{i}$.

The temperature of the chamber was manipulated from 10 to $40^{\circ} \mathrm{C}$ with a constant-temperature water bath. For highertemperature observations of soil fluxes from the soy field soil, the incubation chamber was placed in a container of water on a hotplate. The actual soil temperature was recorded by a small, self-contained temperature data logger with a stainless steel outer casing (iButtons, Maxim Integrated, San Jose, CA, US). In order to prevent the soil from drying out during the analysis, a length of Nafion tubing was placed upstream of the chamber inside a container of distilled water in the same water bath. Even with this precaution, soil samples still dried slightly during the experiment. Samples were weighed daily, and soil moisture content was altered or maintained by adding distilled water. When water content was changed, soil samples were held at $20^{\circ} \mathrm{C}$ and COS flux observations continued for at least $12 \mathrm{~h}$.

To explore the sensitivity of COS uptake to chamber COS mole fractions, we performed a series of incubations with a freshly collected soil sample from near the original soy field site. The soil sample was air-dried to approximately $2 \%$ VWC then incubated with ambient sweep air and COSfree zero air, which contained $300 \mathrm{ppm} \mathrm{CO}_{2}$ and no detectable COS. The difference between the two treatments helped characterize the effect of COS concentration on observed COS fluxes.

\subsection{Scaling laboratory COS measurements to compare to field observations}

Performing soil incubation experiments allowed for precise manipulation of environmental variables to reveal underlying patterns in soil COS exchange. Soil in situ has an important dimension not represented by these laboratory experiments: depth (Ogee et al., 2015; Sun et al., 2015). Data from this study could represent COS exchange from only the top 
layer of soil. Nonetheless, it would be enlightening to compare controlled experiments to data collected in the field.

A further experiment was performed to estimate the relationship between laboratory, per-gram measurements and field, per-area measurements. Soy field soil was gradually added to a $20^{\circ} \mathrm{C}$ incubation chamber, starting with $50 \mathrm{~g}$ and increasing to $300 \mathrm{~g}$. While the total COS emissions increased with every soil addition, the flux per gram soil increased linearly between 50 and $100 \mathrm{~g}$, then demonstrated saturation behavior with samples greater than $100 \mathrm{~g}$. Thus, all fluxes were scaled up to $100 \mathrm{~g}$ and assumed to represent a soil footprint equal to the area of the incubation chamber base, $0.00779 \mathrm{~m}^{2}$. In short, fluxes were multiplied by a factor of $(100 \mathrm{~g})\left(0.00779 \mathrm{~m}^{-2}\right)\left(60 \mathrm{~s} \mathrm{~min}^{-1}\right)^{-1}$ or $214 \mathrm{~g} \mathrm{~min} \mathrm{~m}^{-2} \mathrm{~s}^{-1}$.

\subsection{Modeling patterns in COS soil fluxes}

The total net COS flux observed from the soils is thought to be the combination of abiotic and biotic fluxes.

$F_{\mathrm{COS}, \text { soil }}=F_{\mathrm{COS}, \text { biotic }}+F_{\mathrm{COS}, \text { abiotic }}$

$F_{\mathrm{COS} \text {,soil }}$ is the net flux of $\mathrm{COS}$, whereas $F_{\mathrm{COS} \text {,biotic }}$ and $F_{\mathrm{COS} \text {,abiotic }}$ represent the contribution of biotic and abiotic processes, respectively. The flux units used here were transformed as described in Sect. 2.2 from pmolCOS min ${ }^{-1} \mathrm{gdrys}^{-1}$ to $\mathrm{pmolCOS} \mathrm{m}^{-2} \mathrm{~s}^{-1}$. Two models were fitted to soy field COS soil flux observations to explain $F_{\mathrm{COS} \text {,biotic }}$ and $F_{\mathrm{COS} \text {,abiotic }}$ separately. First, air-dried soil COS measurements were described using an exponential equation, as in Maseyk et al. (2014).

$F_{\text {COS,abiotic }}=\alpha \exp \left(\beta T_{\text {soil }}\right)$,

where $T_{\text {soil }}$ was the temperature of the soil in ${ }^{\circ} \mathrm{C}$, and $\alpha$ and $\beta$ were parameters determined using the least-squares fitting approach. These driest measurements were assumed to represent the observable fluxes with the least influence from microbial uptake of COS while keeping the soil in tact. This calculation was used to examine potential effects of soil COS production during changes in soil moisture. To disentangle biotic fluxes, the soy field $F_{\mathrm{COS} \text {,abiotic }}$ was then subtracted

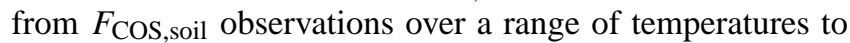
yield $F_{\mathrm{COS} \text {,biotic }}$, as in Eq. (3).

To explain $F_{\mathrm{COS} \text {,biotic }}$, we used a model that was originally developed for soil NO production in Behrendt et al. (2014). Previous work (Van Diest and Kesselmeier, 2008) had used a similar NO soil flux model. The overall form of the equation is the product of a power function and an exponential function, Eqs. (5) and (6).

$$
\begin{aligned}
& a=\ln \left(\frac{F_{\mathrm{opt}}}{F_{\theta g}}\right)\left(\ln \left(\frac{\theta_{\mathrm{opt}}}{\theta_{g}}\right)+\left(\frac{\theta_{g}}{\theta_{\mathrm{opt}}}-1\right)\right)^{-1} \\
& F_{\mathrm{COS}, \text { biotic }}=F_{\mathrm{opt}}\left(\frac{\theta_{i}}{\theta_{\mathrm{opt}}}\right)^{a} \exp \left(-a\left(\frac{\theta_{i}}{\theta_{\mathrm{opt}}}-1\right)\right)
\end{aligned}
$$

Here $a$ is the curve shape constant, $F_{\text {opt }}$ and $F_{\theta g}$ are the

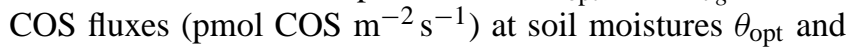

$\theta_{g}$ (percent volumetric water content, $\% \mathrm{VWC}$ ), $F_{\text {opt }}$ is the maximum biotic COS uptake, and $\theta_{\mathrm{opt}}>\theta_{g} . F_{\mathrm{COS} \text {, biotic is }}$ the COS uptake for a given soil moisture $\theta_{i}$ after subtracting $F_{\mathrm{COS} \text {,abiotic }}$ within the specified temperature range. The two models for $F_{\mathrm{COS} \text {,biotic }}$ and $F_{\mathrm{COS} \text {,abiotic }}$ could then be used to predict soil COS fluxes for a given temperature and soil moisture condition.

\subsection{Assessing the importance of soil COS fluxes to the GPP proxy}

Ecosystem COS flux, $F_{\mathrm{COS} \text {,ecosystem }}$, is the sum of leaf COS uptake, $F_{\mathrm{COS}}$,leaf and soil $\mathrm{COS}$ exchange $F_{\mathrm{COS} \text {,soil }}$, including litter. Two approaches were used to explore the error introduced by calculating GPP from ecosystem COS exchange without correcting for $F_{\mathrm{COS} \text {,soil }}$.

The first method sought to calculate temporal variability in the relative importance of $F_{\mathrm{COS} \text {,soil }}$. We used GPP estimates for the soy field FLUXNET site (US-Bo1) based on halfhourly $\mathrm{CO}_{2}$ eddy flux covariance measurements and a respiration model (Reichstein et al., 2005), restricted to values greater than $25 \mu \mathrm{molCO} \mathrm{m}^{-2} \mathrm{~s}^{-1}$ to include only midday fluxes when photosynthesis was high. $F_{\mathrm{COS} \text {, leaf }}$ was anticipated from these reported GPP values, using Eq. (1) with relative uptake of 1.8 (Stimler et al., 2011) and an ambient mixing ratio of $\mathrm{CO}_{2}$ at $380 \mathrm{ppm}$ and of $\mathrm{COS}$ at $500 \mathrm{ppt}$. The model described in Sect. 2.3 was used to generate $F_{\mathrm{COS} \text {,soil }}$ estimates from field soil moisture and temperature data collected at the site. Estimates of $F_{\mathrm{COS} \text {,leaf }}$ and $F_{\mathrm{COS} \text {,soil were }}$ then added together and used to calculate new GPP estimates with Eq. (1). The difference between the reported GPP esti-

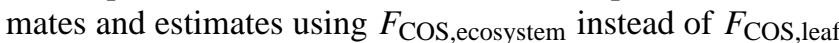
in Eq. (1) was then evaluated.

Secondly, we examined the spatial importance of reported $F_{\text {COS,soil }}$ from the few values reported in the literature, relying on a similar concept as the global calculation above. Using the biome GPP estimates from Beer et al. (2010), we back calculated anticipated estimates of $F_{\mathrm{COS} \text {, leaf }}$ using Eq. (1). For this purposefully simple calculation, we assume a 100day growing season with $12 \mathrm{~h}$ of light per day to convert between annual estimates of GPP and field measurements calculated in $\mathrm{s}^{-1}$ units, though this obviously does not represent the diversity of biome carbon assimilation patterns. For each biome where data existed, a range of $F_{\mathrm{COS}}$,ecosystem was calculated as the estimated $F_{\mathrm{COS} \text {, leaf }}$ added to the range of reported $F_{\mathrm{COS} \text {,soil }}$ from previous studies. A GPP estimate

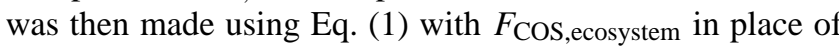
$F_{\text {COS,leaf }}$ The percentage difference between the GPP estimate in Beer et al. (2010) and this new GPP estimate was then evaluated. 


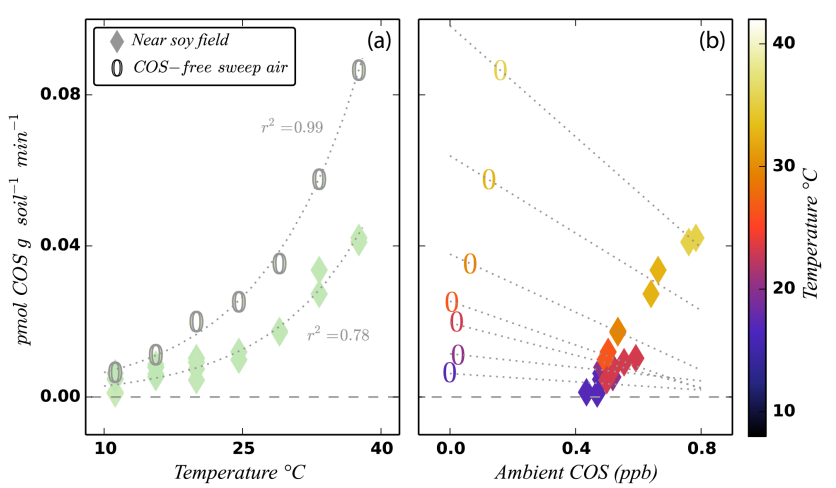

Figure 4. Net COS exchange over temperature from a soil sample taken near the original soy field site: fluxes observed under ambient sweep air and COS-free sweep air conditions with exponential leastsquares regression lines (a), and the relationship between ambient chamber COS concentrations and observed fluxes with linear leastsquares regression lines (b).

\section{Results}

With the exception of the soy field sample, soils investigated here exhibited net COS exchange rates much lower than anticipated leaf COS uptake, ranging from -8 to $+8 \mathrm{pmolCOS} \mathrm{m}^{-2} \mathrm{~s}^{-1}$, compared to leaf uptake rates of -27 to -42 pmol COS m ${ }^{-2} \mathrm{~s}^{-1}$ (Stimler et al., 2011). The sensitivity of COS soil exchange to COS ambient concentrations is presented in Sect. 3.1. The overall patterns of COS exchange over temperature and soil moisture gradients are described in Sects. 3.2 and 3.3. The soil samples from the soy field had the highest overall fluxes: the biotic and abiotic components of these fluxes are investigated in Sect. 3.4.

\subsection{COS mixing ratios and COS net fluxes}

Altering the mixing ratio of COS in the chamber sweep air had a strong effect on COS exchange with a soy field soil sample. The slopes of the linear regression lines in Fig. $4 \mathrm{~b}$ represent the change in COS flux of the soil sample divided by the change in ambient COS. The slopes are all negative and become strictly steeper as temperature increases. Under ambient and zero air treatments, the soil sample showed exponentially higher net COS emissions with temperature. Apparent uptake increased with more available COS in the headspace. The linear regression intercepts in Fig. $4 \mathrm{~b}$ and graphed separately in Fig. 5b represent the theoretical flux we would expect if there were no COS in the chamber at all. This soil sample exhibited net emissions of COS at all temperatures; therefore, the headspace always contained some small amount.

The COS mixing ratios observed in laboratory air during the entire course of experiments was $510 \pm 80$ ppt. The mixing ratio observed at the outlet was $470 \pm 95$ ppt COS. To calculate the maximum anticipated effect of this range,
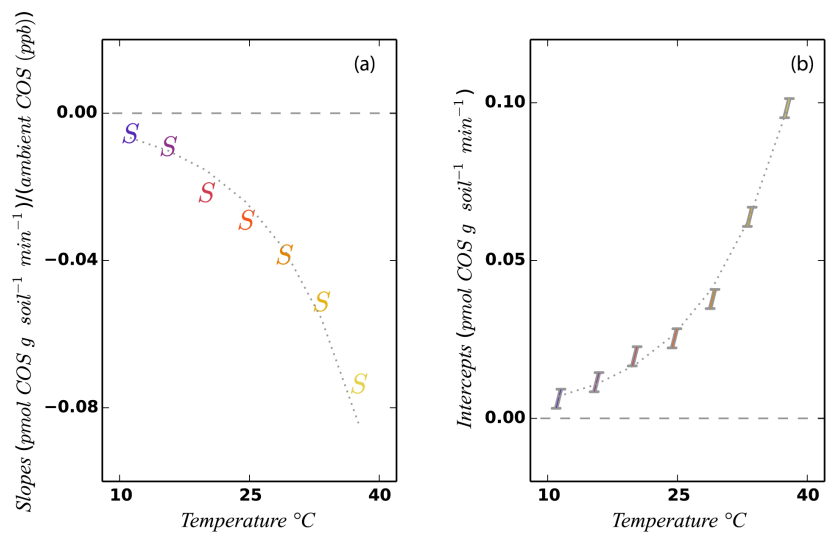

Figure 5. Slopes (a) and intercepts (b) of the linear least-squares regression lines in Fig. 4b and their exponential linear least-squares regression relationship with incubation temperature (dotted lines).
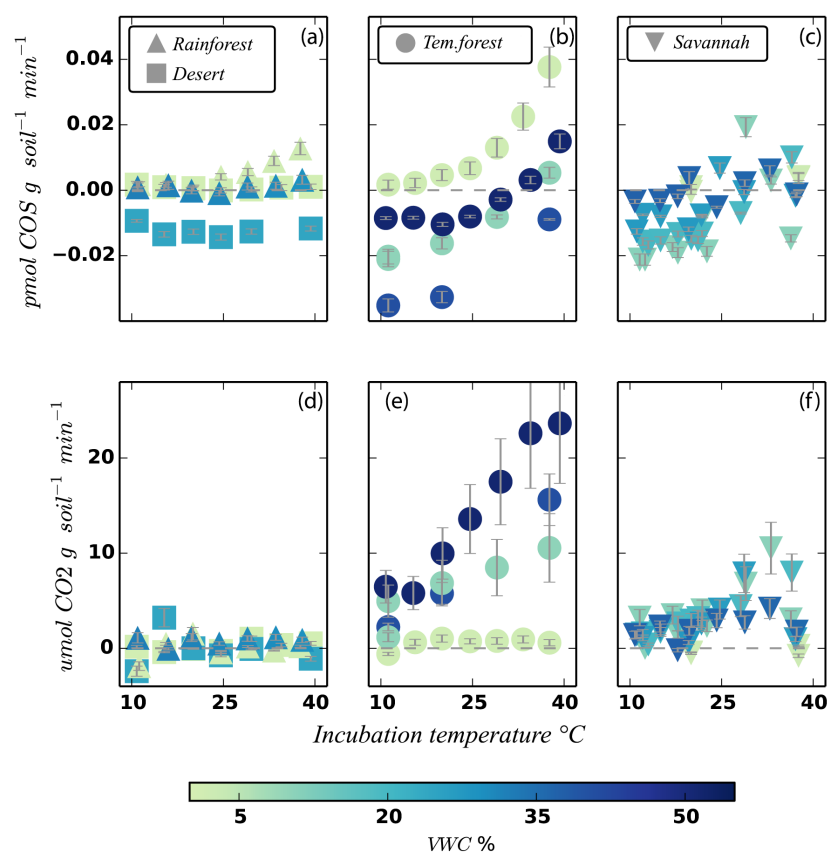

Figure 6. $\mathrm{CO}_{2}$ and $\mathrm{COS}$ flux observations over a range of temperatures and soil water content. See soil sample descriptions in Table 1.

we used the maximum slope observed for the linear relationship described in Kesselmeier et al. (1999) for soils at $17^{\circ} \mathrm{C}$ at a specific volumetric water content: $F_{\mathrm{COS} \text {,uptake }}=$ $0.006 \times[\mathrm{COS}]-0.32$, where soil COS uptake, $F_{\mathrm{COS} \text {,uptake, }}$ is reported in pmol COS g $\mathrm{g}^{-1} \mathrm{~h}^{-1}$ and [COS] is the mixing ratio of COS in ppt. The variability of COS mixing ratios in the soil chamber calculated by this method would cause a variability of $\pm 0.019 \mathrm{pmol}$ gram dry $\mathrm{soil}^{-1} \mathrm{~min}^{-1}$. By our simplified scaling presented in Sect. 2.2, this translates to 4.1 $\mathrm{pmolCOS} \mathrm{m}^{-2} \mathrm{~s}^{-1}$. 


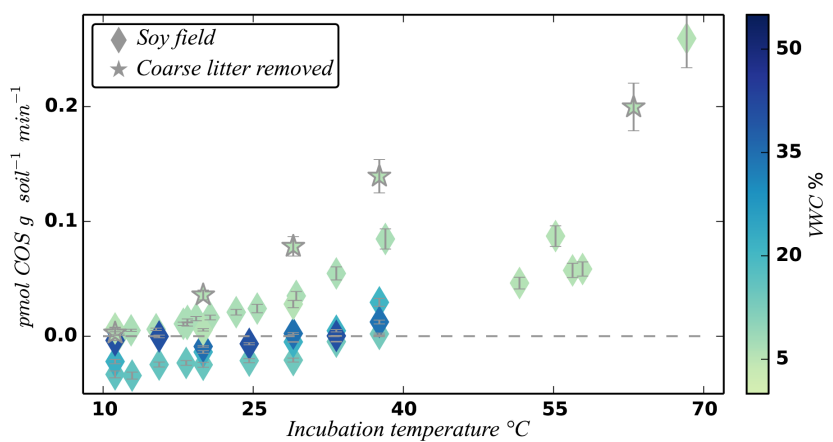

Figure 7. COS net exchange from a soy field soil. For one series of observations, the sand-sized fraction (represented by stars) was removed from a sample by wet sieving, then incubated as before.

\subsection{COS soil flux observations with temperature}

Overall, desert and rainforest samples had the smallest magnitude net COS exchange rates. The temperate forest samples showed the largest net uptake during the first trials, when the soil sample was at field soil moisture, $41 \%$ VWC. Of the small fluxes presented in Fig. 6, temperate forest soils also had the largest net production when the soil sample was in its hottest and driest state (Fig. $6 \mathrm{~b}, 38^{\circ} \mathrm{C}$ and $5 \%$ VWC). Samples from the oak savannah displayed variable fluxes (Fig. 6c). Observations with the soy field soil generated mostly net production of COS, often 10 times greater than fluxes from other soil samples (Fig. 7).

COS fluxes tended towards more positive fluxes with hotter temperatures (Figs. 6 and 7). Soils incubated at $40^{\circ} \mathrm{C}$ exhibited net $\operatorname{COS}$ production while incubations at $10^{\circ} \mathrm{C}$ yielded net COS consumption in a majority of cases. Except for the desert site, the areas where these soils were collected rarely experienced such high maximum soil temperatures, if at all (Fig. 1).

The temperate forest showed the highest $\mathrm{CO}_{2}$ fluxes, with increasing fluxes for increasing temperatures and soil moisture (Fig. 6e), contrasted by the small fluxes from the rainforest and desert soils (Fig. 6d). The savannah soils exhibited an optimum temperature for $\mathrm{CO}_{2}$ fluxes near approximately $30^{\circ} \mathrm{C}$ (Fig. 6f).

The soybean agricultural soil incubations yielded net COS emissions for the majority of trials, with a larger range than the other soils investigated: -0.04 to $0.09 \mathrm{pmolCOS} \mathrm{g}^{-1} \mathrm{~min}^{-1}$ when incubated between 10 and $40^{\circ} \mathrm{C}$. When samples of the agricultural soil were heated further, COS net production persisted. To determine the contribution of soil organic matter in the sand-sized fraction (SSF), coarse litter $>53 \mu \mathrm{m}$ was removed from one subsample and incubated as before. COS net emissions were higher compared to non-sieved samples at similar temperature and water content (Fig. 7).

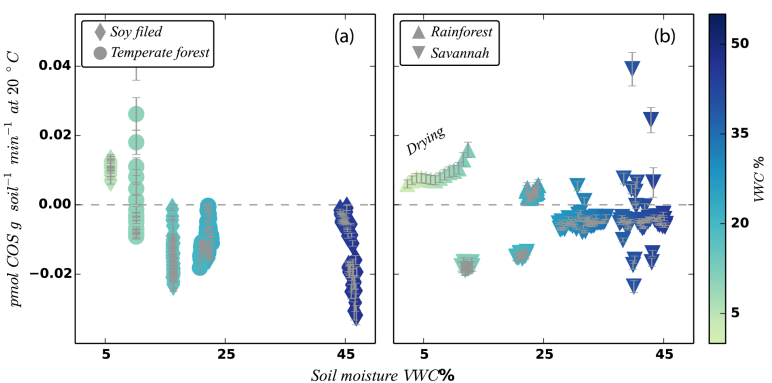

Figure 8. COS flux observations at $20^{\circ} \mathrm{C}$ after soil water content manipulation for soy field and temperate forest soils (a) and rainforest and savannah soils (b). A rainforest soil sample in (b) was intentionally dried out by removing the Nafion tubing in the experimental setup (see Fig. 3).

\subsection{COS soil flux observations with soil moisture}

Soil COS fluxes had a more complicated relationship with soil moisture. When soil samples were waterlogged, net COS exchange shifted towards zero compared to drier trials. For the most part, drier soils have net emissions of COS, except in the case of the varied fluxes from the oak savannah soil (Figs. 6 and 7). In oak savannah soil, increases in soil moisture led to increases in COS uptake. When soil moisture was increased further to near $40 \%$ VWC, COS exchange returned to near zero. The savannah site was expected to experience this range of soil moisture (Fig. 1). In contrast, where dry rainforest soil experienced an increase in net COS production, rainforest soil rarely experiences near-zero soil moisture (Fig. 1). Increasing water content to field levels, the rainforest soil COS exchange returned to near zero. This does not take into account the fluctuations in soil moisture and redox potential experienced in a rainforest in situ. Temperate forest soils appear to experience net COS uptake except under very dry or unusually hot conditions (Fig. 6b).

To observe changes in COS fluxes during changes in soil moisture (i.e., as would happen in situ via precipitation), COS exchange was recorded for at least $12 \mathrm{~h}$ after soil moisture was changed during the course of the experiment (Fig. 8). The rainforest and savannah fluxes showed no discernible pattern in fluxes after water additions. For one series of observations with rainforest soil, the Nafion tubing was removed and the soil dried slowly over time, continuing to show little variability. In contrast, the temperate forest and soy field soils (Fig. 8a) responded with a large variability in COS fluxes after soil moisture manipulation, taking several hours to reach a consistent flux value. There was an overall negative relationship between soil moisture and net COS production for the soy field soil samples, but the link between soil moisture and COS fluxes for soils collected at other sites is not as clear. 


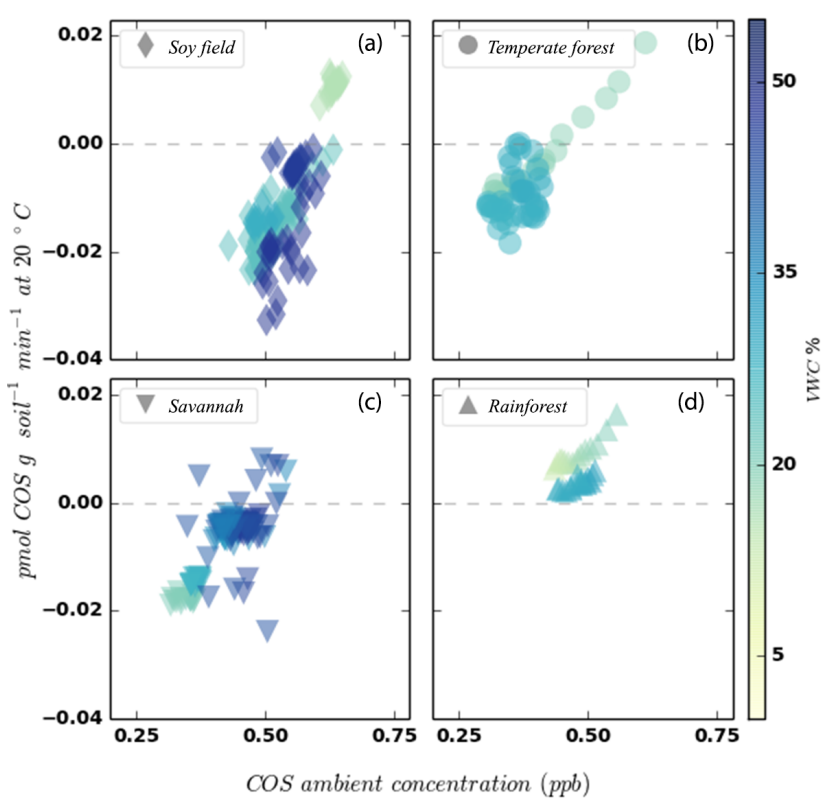

Figure 9. The mixing ratio of $\mathrm{COS}$ exiting the incubation chamber versus $\mathrm{COS}$ fluxes after water addition at $20^{\circ} \mathrm{C}$.

To test whether the COS mixing ratio controls the variation seen in Fig. 8, we examined the mixing ratio of COS exiting the chamber versus COS exchange (Fig. 9), and we find that no clear relationship emerges. Additionally, high COS production does not appear to obscure the relationship between COS ambient mixing ratios and COS uptake. As a thought exercise to demonstrate this, we estimated the COS production component of soil fluxes and subtracted it from the net fluxes depicted in Fig. 9, shown in Fig. 10. When soils were air-dried then incubated, a net COS emission was observed with a positive relationship to temperature ranging from 10 to $40^{\circ} \mathrm{C}$ for all the samples except the desert soil. Using Eq. (4) and least-squares regression, a curve was generated for all soil types investigated other than the desert soils, shown in Fig. 11 and Table 2. We did not generate enough data to characterize the relationship in savannah soils. Correcting for COS production in this way does not change the overall relationship between incubation COS mole fraction and observed COS fluxes. The production of COS is assumed to be insensible to the concentration of COS the soil experiences, depending here only on temperature. From examination of Fig. 11, it can be seen that the correction for abiotic production at $20^{\circ} \mathrm{C}$ is a small portion of the overall magnitude of the fluxes. Using this purposefully simple model (Eq. 3) to subtract out the effects of COS production vertically shifts the data and does not change the pattern of the relationship, as shown in Fig. 10.

COS fluxes change over time after a change in soil water content was not consistent for given changes in soil moisture. However, when water was added to dry soil ( $<10 \%$ VWC), many soil subsamples exhibited the pattern in Fig. 12b: $\mathrm{CO}_{2}$

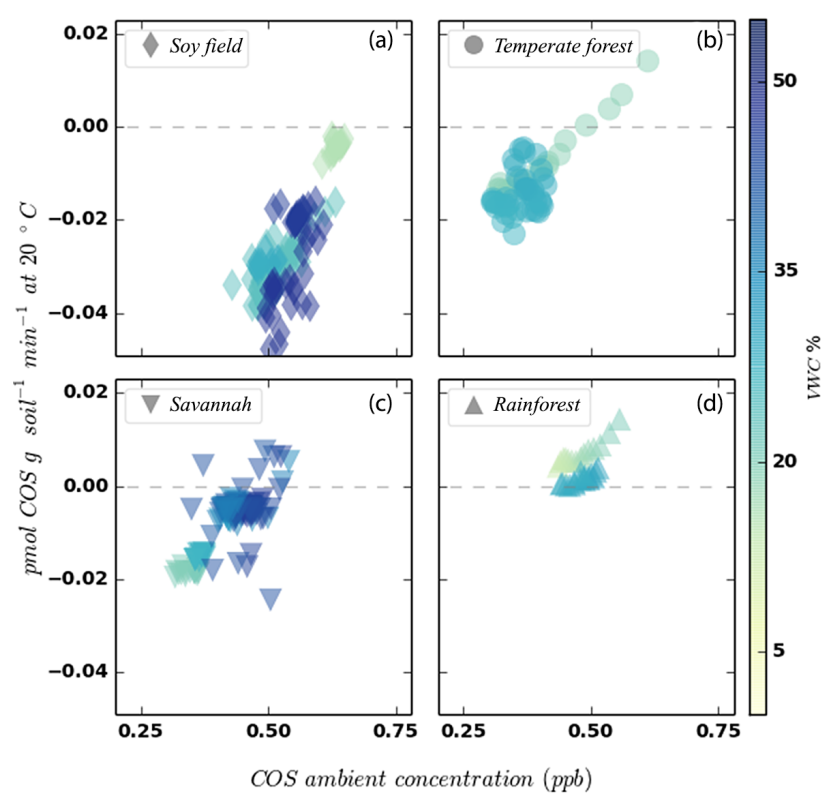

Figure 10. Soil COS mole fractions and soil COS flux after water addition at $20^{\circ} \mathrm{C}$ with subtraction of anticipated COS production shown in Fig. 11.

fluxes remained consistent, while COS fluxes increased immediately after water addition, then slowly decreased over many hours. This is contrasted by Fig. 12a, where both COS and $\mathrm{CO}_{2}$ fluxes demonstrate some variability after changes in water content.

\subsection{Modeling soil COS production and consumption}

Net COS fluxes were a balance of abiotic and biotic processes. If we assume that incubations of air-dried agricultural soils were representative of an abiotic COS production or desorption (less some physical limitations), we can calculate the relationship between abiotic COS production and temperature for agricultural soil (plotted in Fig. 13a). We fitted Eq. (4) to the data scaled as described in Sect. 2.2 and using a least-squares approach, much like in Maseyk et al. (2014). The resulting Eq. (7) had an $r^{2}$ value of 0.9.

$F_{\mathrm{COS}, \text { abiotic }}=0.437 \exp \left(0.0984 T_{\text {soil }}\right)$

There were more cold $\left(<15^{\circ} \mathrm{C}\right)$ incubations performed than hot $\left(>35^{\circ} \mathrm{C}\right)$ incubations, and some of the coldest incubations were excluded from the fit to give appropriate weight to the hottest incubations.

Subtracting the dry soy field soil signal component from all other COS incubation results, we found the biotic and physically limited flux component (Fig. 13b). The COS incubation observations had been converted to $\mathrm{pmolm}^{-2} \mathrm{~s}^{-1}$ units, binned by incubation temperatures as $<20,20-30$, and $>30^{\circ} \mathrm{C}$, fitted to Eq. (6) and plotted in Fig. 13b. The result- 
Table 2. Fitting parameters for air-dried soils versus temperature, found by least-squares regression curve fitting to Eq. (4).

\begin{tabular}{lrr}
\hline Soil origin & $\exp (\alpha)$ & $\beta$ \\
\hline soy field & -6.12 & 0.096 \\
temperate forest & -7.77 & 0.119 \\
savannah & -9.54 & 0.108 \\
rainforest & -8.2 & 0.101 \\
\hline
\end{tabular}

Table 3. Fitting parameters using Eq. (6) for soy field COS fluxes binned by temperature. See Sect. 4.2 for parameter descriptions. Fluxes are in pmol $\operatorname{COS~} \mathrm{m}^{-2} \mathrm{~s}^{-1}$ and soil moistures are in percentage volumetric water content (\% VWC).

\begin{tabular}{lrrrrr}
\hline Temperature bin $\left({ }^{\circ} \mathrm{C}\right)$ & $F_{\text {opt }}$ & $\theta_{\text {opt }}$ & $F_{\theta g}$ & $\theta_{g}$ & $r^{2}$ \\
\hline $10-20$ & 8.38 & 18.7 & 1.40 & 37.2 & 0.8 \\
$21-30$ & 11.6 & 21.9 & 9.99 & 28.6 & 0.8 \\
$31-40$ & 14.8 & 25.8 & 8.48 & 47.6 & 0.6 \\
\hline
\end{tabular}

ing parameters are shown in Table 3. For the purposes of generalizing the equation to any temperature and moisture content pairing, $\theta_{g}$ was held constant at $35 \% \mathrm{VWC}$; thereafter the data were binned by different temperature increments to discern how $F_{\mathrm{opt}}, F_{\theta g}$, and $\theta_{\mathrm{opt}}$ in Eqs. (5) and (6) change with temperature. More data need to be collected to create a robust model; however, we think this is a worthwhile attempt at capturing variability.

$$
\begin{aligned}
& F_{\text {opt }}=-0.00986 T_{\text {soil }}^{2}+0.197 T_{\text {soil }}+-9.32 \\
& \theta_{\text {opt }}=0.287 T_{\text {soil }}+14.5 \\
& F_{\theta g}=-0.0119 T_{\text {soil }}^{2}+0.110 T_{\text {soil }}+-1.18
\end{aligned}
$$

The total flux $F_{\mathrm{COS} \text {,soil }}$ can be calculated as the sum of fluxes generated by biotic and abiotic processes.

Using this framework of equations, we estimate the influence of large soil COS fluxes on GPP estimates. We used data reported for the Bondville FLUXNET site, US-Bo1, the soy field site in this study. The model shown in Fig. 13 and described in Eqs. (3)-(10) was based on flux observations from soil collected at this site. There are well-known uncertainties associated with reported GPP from flux towers (Desai et al., 2008). However, since we have no in situ measurements of COS from the site, these data are used as a starting point for calculating theoretical error potentials.

Two GPP estimates are presented in Fig. 14a: the first represents GPP estimates with COS leaf uptake fluxes alone, the second was based on theoretical net COS fluxes, including both leaf and soil COS exchange calculated with Eq. (3). The difference between the 1-day moving averages (Fig. 14b) signifies how GPP could have been over- or underestimated if net ecosystem COS fluxes were used as leaf uptake fluxes, ranging from -5 to $+25 \%$.

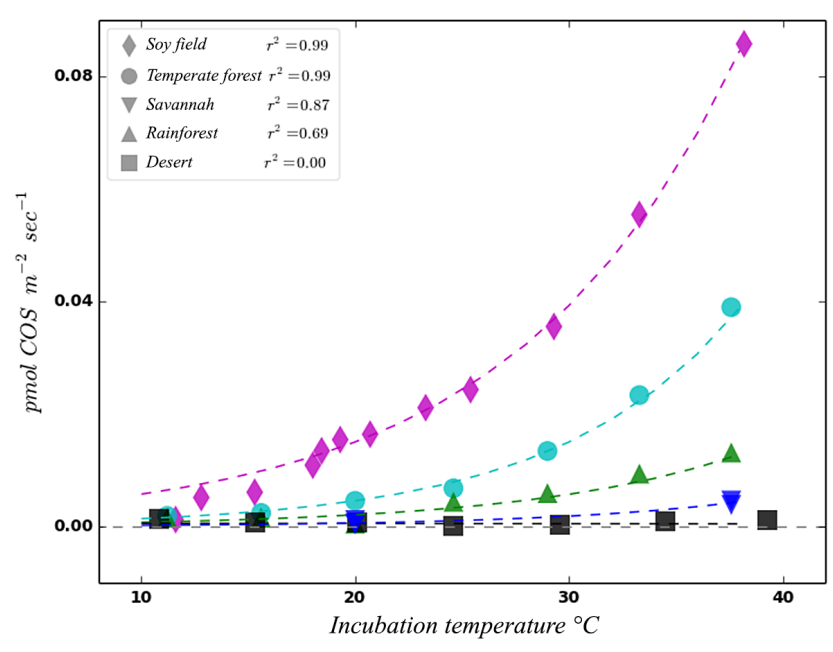

Figure 11. Observations of COS fluxes from air-dried soils over a range of temperatures. Air-dried soils experience negligible COS uptake; the net fluxes here are assumed to be soil COS production only. Equation (4) was used to curve-fit the relationship between temperature and soil COS production with least-squares regression. The $r^{2}$ values of this attempt are shown in the figure legend.

To explore the possible spatial variation in soil COS exchange influence on the GPP proxy, we perform a similar calculation (described in Sect. 2.4) using in situ soil fluxes from previous studies (Table 4). The potential error in GPP estimates based on these sparse measurements ranges from -220 to $+119 \%$. More observations and modeling of soil COS exchange for different ecosystems could ameliorate this large error.

\section{Discussion}

Generally, non-wetland soils are thought to have a small COS exchange rate compared to uptake by plant leaves. This assumption is based on few chamber measurements, often by severely altering the ecosystem, e.g., extracting plants beforehand (see review in Whelan et al., 2013). During a campaign to measure COS by eddy flux covariance in Oklahoma, Billesbach et al. (2014) noticed that hot soil and particularly hot and dry soil yielded emissions of COS to the atmosphere. This is believed to be a breakdown product from thermal decomposition of soil organic matter (Maseyk et al., 2014; Whelan and Rhew, 2015). This study sought to investigate the ubiquity of this phenomenon by incubating soils from a broad range of ecosystems and under a matrix of controlled conditions. Here we have found that, as assumed previously, most soils have small COS fluxes relative to anticipated plant uptake. However, large emissions like those reported by Billesbach et al. (2014) were generated in incubations of another agricultural soil from a soy field over $800 \mathrm{~km}$ away (Fig. 2). 


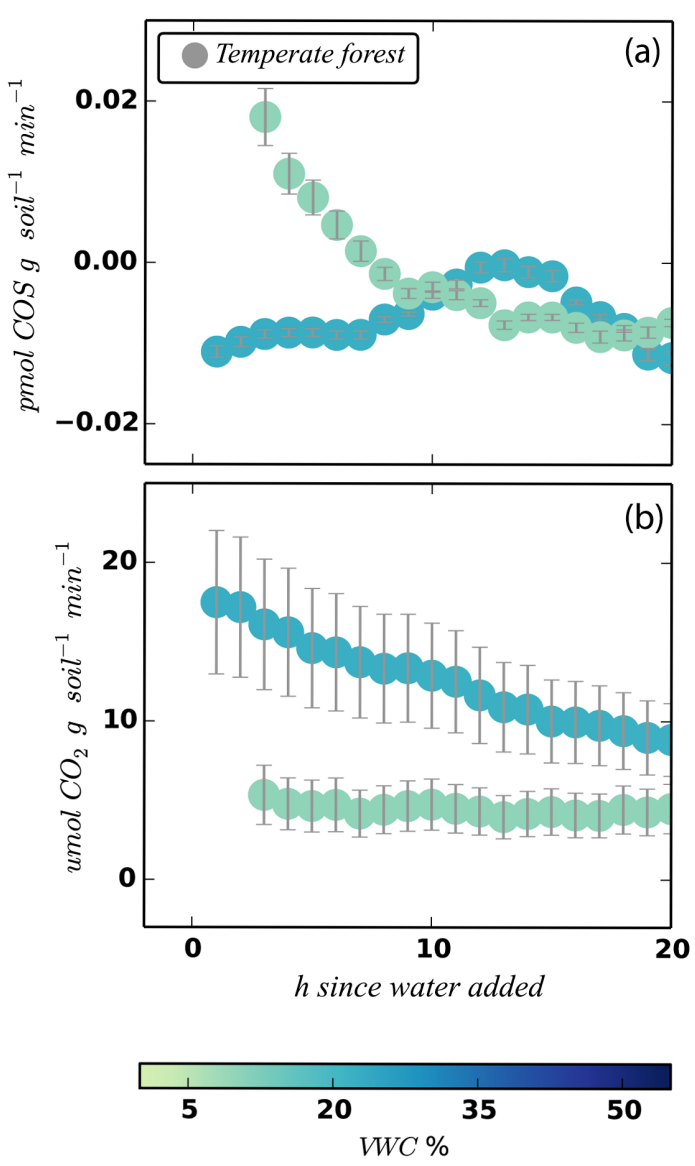

Figure 12. COS fluxes over time after temperate soil moisture content was changed from (a) 10 to $22 \% \mathrm{VWC}$ and (b) $2 \%$ (air-dried) to $10 \% \mathrm{VWC}$, incubated at $20^{\circ} \mathrm{C}$.

\subsection{Potential effects of ambient COS concentration on COS exchange}

Previous studies have shown that the interaction between net fluxes and ambient concentration of COS is linear (e.g., Conrad, 1994; Kesselmeier et al., 1999). COS soil fluxes have a demonstrated "compensation point", the atmospheric concentration of COS where the net flux of a specific system is 0 . At concentrations below the compensation point, net emission to the atmosphere is observed; net consumption is observed when ambient concentrations are higher than the compensation point. We believe that the variability in fluxes due to changes in soil moisture in Fig. 8 masks the effect of changes in COS chamber mixing ratios. In Kesselmeier et al. (1999), the authors used the mole fraction of COS exiting the incubation chamber as a measure of the well-mixed ambient environment actually experienced by the soil. The relationship between the observed COS fluxes after soil moisture change and the COS mixing ratio exiting the chamber is depicted in Fig. 9; all incubations depicted took place at $20^{\circ} \mathrm{C}$. If the controlling variable of the net fluxes in Fig. 9 was am-

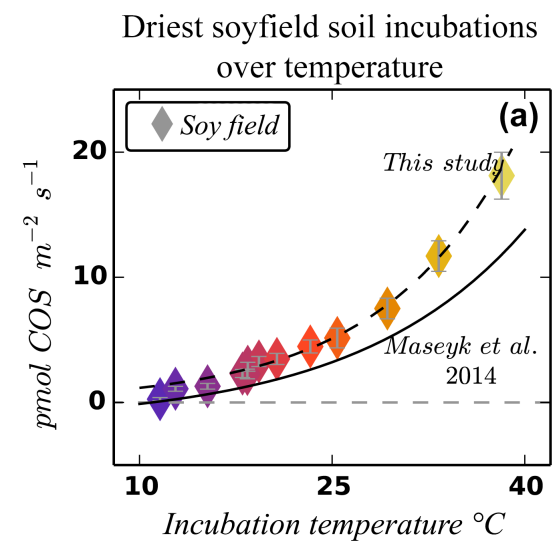

Total COS fluxes minus driest fluxes

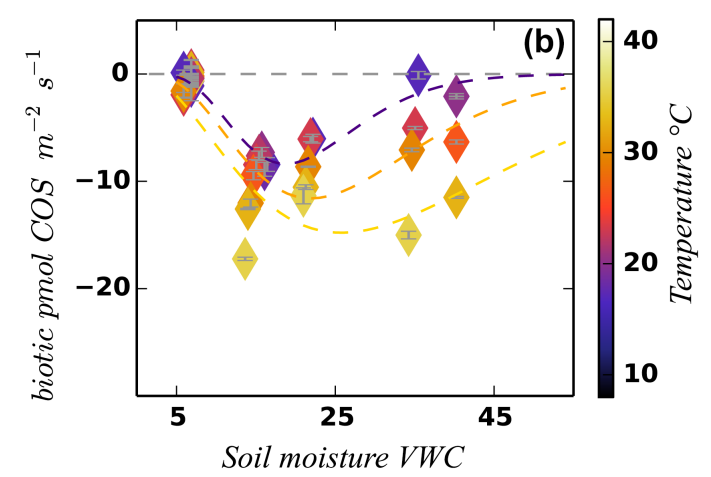

Figure 13. Estimated fluxes from abiotic (a) and biotic (b) processes of soil COS exchange from soy field soil. In (a), COS fluxes from the driest trials $(\mathrm{VWC} \approx 6 \%$ ) were related to temperature by Eq. (4). The empirically derived relationship for soils with soil moisture content less than $20 \%$ VWC from Maseyk et al. (2014) is plotted for comparison. In (b), COS fluxes from soy field soil were transformed by subtracting the anticipated driest flux using Eq. (3). A model of COS consumption, Eqs. (5) and (6), was applied to the resulting data, binned into groups of incubations $<21^{\circ} \mathrm{C}$ (indigo), $>30^{\circ} \mathrm{C}$ (yellow), and the range in between (orange). The parameters of the least-squares fit for each temperature bin can be found in Table 3.

bient COS, one would expect a strong inverse linear relationship where higher concentrations of COS result in higher uptake of COS at a particular soil moisture state. Instead, we see a positive relationship between COS mole fraction and COS flux. This is not surprising, because higher soil COS production leads to more COS leaving the chamber. Perhaps there is a dampening effect on COS fluxes, where net COS production by soils increases soil COS consumption, but the overall effect is overwhelmed by high COS production. In other words, the net production reported here may be in reality higher at the lower ambient COS mixing ratios that would be encountered by unenclosed soils in the field. However, when COS production was estimated and taken into account (Fig. 10), the overall pattern was unchanged. 
Table 4. The error introduced to GPP estimates when COS soil fluxes are held negligible. The \% uncertainty column describes how much GPP would be overestimated, as a percentage of GPP calculated by Beer et al. (2010), if soil COS uptake determined from chamber measurements was included in the $F_{\mathrm{COS} \text {,leaf }}$ term. Negative values indicate underestimated GPP. Numbers reported for soil COS exchange were often based on a small number of observations, sometimes after forced removal of plants.

\begin{tabular}{|c|c|c|c|c|c|c|}
\hline Biome & $\begin{array}{r}\text { GPP estimated } \\
\text { by Beer et al. (2010) } \\
\text { in } \mathrm{Pg} \mathrm{C} \mathrm{yr}^{-1}\end{array}$ & $\begin{array}{l}\text { Biome area } \\
\text { in } 10^{9} \text { ha }\end{array}$ & $\begin{array}{l}F_{\text {COS,soil from }} \\
\text { field studies in } \\
\text { pmol m}^{-2} \mathrm{~s}^{-1}\end{array}$ & $\begin{array}{r}\text { Anticipated } \\
F_{\mathrm{COS} \text {,leaf }} \\
\text { in } \mathrm{pmolm} \mathrm{m}^{-2} \mathrm{~s}^{-1}\end{array}$ & $\begin{array}{r}\% \text { uncertainty in } \\
\text { GPP by neglecting } \\
\text { soil COS }\end{array}$ & $F_{\mathrm{COS}, \text { soil }}$ field studies \\
\hline Croplands & 14.8 & 1.35 & -18 to 40 & -48 & +37 to -83 & $\begin{array}{l}\text { Post-harvest soil exchange estimate from the } \\
\text { wheat field from Billesbach et al. (2014). }\end{array}$ \\
\hline $\begin{array}{l}\text { Temperate grasslands, } \\
\text { shrublands }\end{array}$ & 8.5 & 1.78 & -13.3 to -8.8 & -21 & +119 to -34 & $\begin{array}{l}\text { Range reported in Kuhn et al. (1999) as an up- } \\
\text { per limit. }\end{array}$ \\
\hline Temperate forests & 9.9 & 1.04 & -8 to 1.45 & -42 & +20 to -3 & $\begin{array}{l}\text { Range from Castro and Galloway (1991), Stein- } \\
\text { bacher et al. (2004), White et al. (2010), and Yi } \\
\text { et al. (2007). }\end{array}$ \\
\hline Boreal forests & 8.3 & 1.37 & 1.2 to 3.8 & -27 & -5 to -14 & $\begin{array}{l}\text { The average and } 1 \text { standard deviation from plots } \\
\text { having less than } 10 \% \text { vegetation cover (Sim- } \\
\text { mons, 1999) }\end{array}$ \\
\hline Tundra & 1.6 & 0.56 & 5.27 to 27.6 & -13 & -42 to -220 & $\begin{array}{l}\text { The lower production is from De Mello and } \\
\text { Hines (1994). The larger production value is an } \\
\text { average estimate from Fried et al. (1993) }\end{array}$ \\
\hline Deserts & 6.4 & 2.77 & No data & -6 & No data & No data \\
\hline $\begin{array}{l}\text { Tropical savannahs, } \\
\text { grasslands }\end{array}$ & 31.3 & 2.76 & No data & -32 & No data & No data \\
\hline Tropical forest & 40.8 & 1.75 & No data & -102 & No data & No data \\
\hline
\end{tabular}

The soil samples in this study were incubated under flowing air. The soil and headspace air were assumed to be in equilibrium after $30 \mathrm{~min}$. If that were true, adsorption and desorption should no longer contribute to the soil flux: equal amounts of COS should adsorb and desorb. The uptake difference between the zero air and ambient air treatments in Fig. 4 indicates that some uptake process was affecting net soil fluxes, even in a very dry soil.

\subsection{Mechanisms of soil COS exchange}

Multiple mechanisms determined the net COS exchange from soil, which were affected by soil water content and temperature. There are three proposed abiotic processes: COS production from abiotic degradation of soil organic matter (Whelan and Rhew, 2015), the physical limitations of water restricting air exchange between soil pore spaces and the chamber headspace (Van Diest and Kesselmeier, 2008), and adsorption/desorption of COS onto soil grains. The biotic uptake of COS by soils is theorized to be via enzymes present in the microbial community that are similarly responsible for COS uptake in plants (Kesselmeier et al., 1999; ProtoschillKrebs et al., 1996). There is no known biotic COS production mechanism in soils.

Taking these routes of COS exchange into account, we can explain qualitatively the fluxes observed here. For example, hot, dry soil appeared to produce the highest net COS emissions. Dry soil has a smaller active microbial community (Manzoni et al., 2011), and biotic uptake would be small. Higher temperatures should yield more thermal degradation of organic matter, resulting in higher COS production. In this study, when soy field soils were heated from 40 to $68^{\circ} \mathrm{C}$, COS net emissions continued, suggesting that the trace gas production here had no optimum temperature and was most likely abiotic (Conrad, 1996). Simultaneously, COS within the soil would exchange with the chamber air without the added tortuosity of water-filled pore space. The overall result is more COS produced abiotically, less COS consumed biotically, and the resulting COS excess diffusing quickly out of the soil. After wet-up, the temperature response curve shifts towards a COS sink, though it often retains a similar shape. When soil moisture is increased further, soil pore spaces are effectively cut off from the chamber headspace. When waterlogged, the soil exhibits COS fluxes nearer to 0 regardless of temperature. This reasoning evidently holds across the temperate forest, savannah, and agricultural soil investigated here.

The desert soil samples, however, demonstrated near-zero COS exchange at field moisture and COS uptake when wetted. Since these soils are frequently hot and dry, it could be that there is not sufficient remaining organic material to abiotically degrade into COS, or there are not enough clay or silt surfaces for COS to adsorb/desorb. The behavior of the desert soil resembles the soil COS exchange observed in Van Diest and Kesselmeier (2008) and Kesselmeier et al. (1999), which both investigated exclusively sandy soils. 


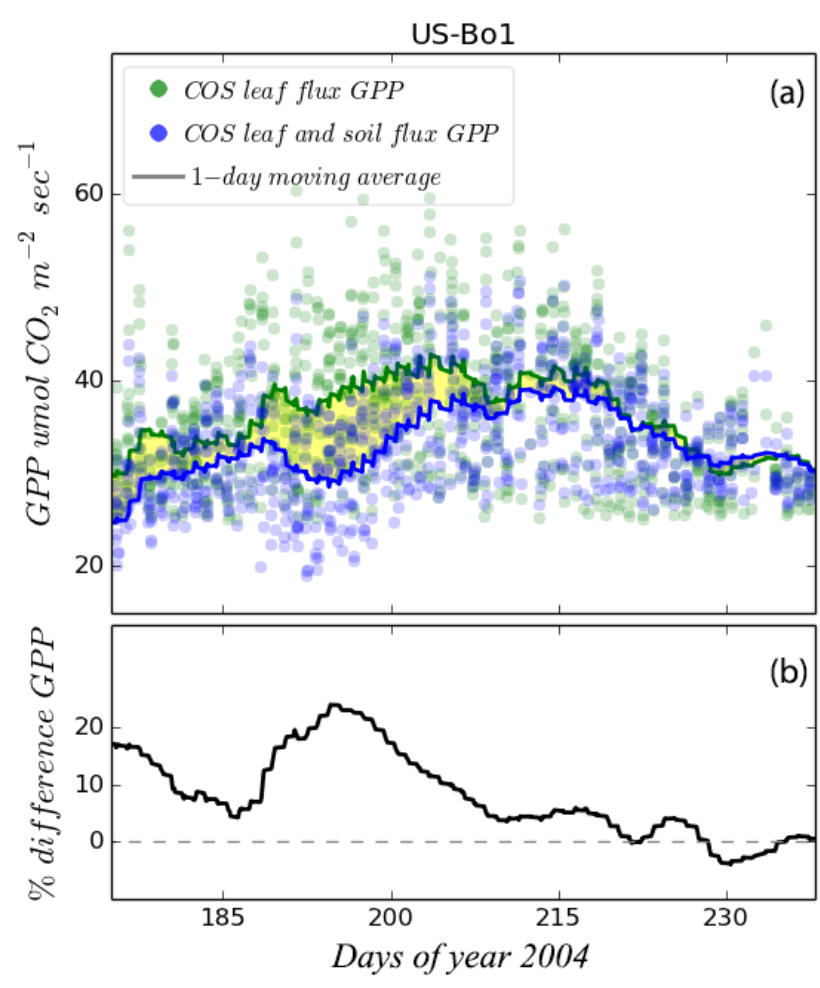

Figure 14. Comparing theoretical GPP estimates based on gross COS leaf fluxes vs. net ecosystem COS fluxes. (a) Theoretical GPP estimates based on leaf COS uptake, GPP estimates based on net ecosystem COS fluxes calculated by Eqs. (1) and (3), and their moving averages for a $24 \mathrm{~h}$ window. The yellow shaded region highlights the difference between the reported GPP and the COS-GPP proxy when no soil correction is made. (b) The percentage difference between the 1-day moving average of reported GPP and the calculated COS flux-GPP estimates with modeled soil COS exchange included.

\subsection{More COS generated from agricultural soil}

For the agricultural soils studied here, it appears that some soil interaction produced much more COS than other soils investigated. Large COS emissions were also observed from a wheat field soil in China (Liu et al., 2010) and the previously mentioned wheat field in Oklahoma (Billesbach et al., 2014; Maseyk et al., 2014; Whelan and Rhew, 2015), but not from the sandy arable soil in Germany, Finland, and China (Van Diest and Kesselmeier, 2008), where only net COS uptake was observed. While Melillo and Steudler (1989) found increases in forest soil COS production coincident with nitrogen fertilizer application, the composition of fertilizer used at the sites discussed above is unknown to us. It is unclear what is particular about the agricultural soils in the study by Van Diest and Kesselmeier (2008) that should result in only soil COS net consumption.

Two hypotheses emerge from the theoretical framework detailed above. The first is that all soils experience large COS production from thermal degradation of soil organic matter

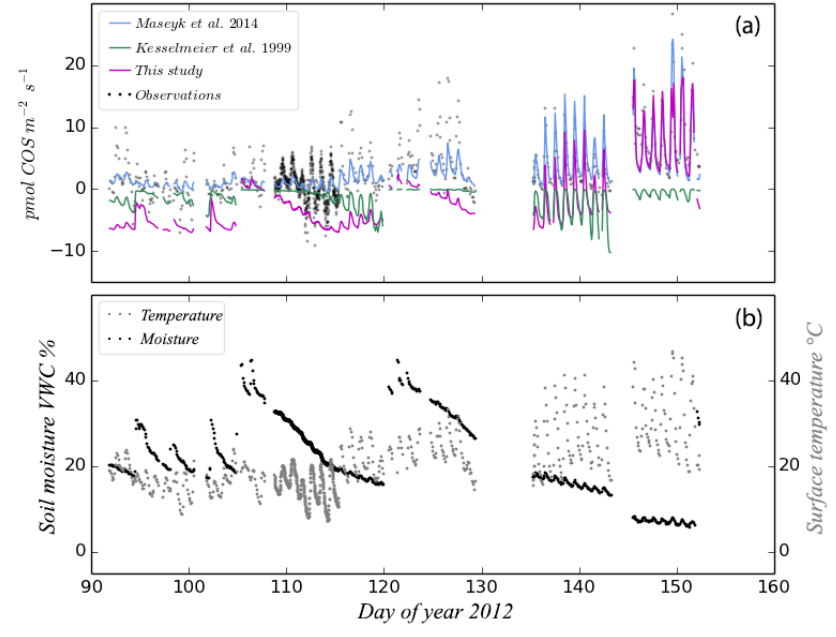

Figure 15. Comparing the model developed here with field observations. (a) Soil chamber COS flux observations and the empirically derived relationship between COS fluxes, soil moisture, and surface temperature from Maseyk et al. (2014) and this study (Eq. 3) - the model developed by Kesselmeier et al. (1999) as described in Kettle et al. (2002) adjusted for $10 \mathrm{pmol} \mathrm{m}^{-2} \mathrm{~s}^{-1}$ as a maximum magnitude uptake. COS soil fluxes were measured using an automatic soil chamber containing no wheat. (b) Environmental variables observed at the Southern Great Plains ARM site in Oklahoma from Maseyk et al. (2014).

or desorption from soil surfaces, but most or all COS generated is usually consumed by in situ microbial communities. The agricultural soils collected in Oklahoma and Illinois undergo pesticide/herbicide applications and irrigation during the course of their management that may limit the diversity and size of the microbial community (Griffiths and Philippot, 2013) and the magnitude of the microbial COS sink. This idea is partially supported by Whelan and Rhew (2015), where autoclaved agricultural soils only experienced net COS production, though autoclaved soils are known to emit COS (Kato et al., 2008).

The second hypothesis suggests that the accessibility of the agricultural soil organic matter allowed more abiotic COS production than in forest or savannah soils. This could also be due to agricultural land management practices, which tend to break down soil aggregates and destabilize soil organic matter (Sollins et al., 1996). Accessibility, rather than litter quality, could explain why we see a similar COS production from agricultural fields with different crop cover, i.e., wheat (Billesbach et al., 2014; Liu et al., 2010) and soy/corn (this study). However, this still does not explain the biotically driven net COS uptake patterns found in arable soils by Van Diest and Kesselmeier (2008) and Kesselmeier et al. (1999), who report COS fluxes that resemble more the desert soil fluxes investigated here.

These two hypothesis may both influence COS exchange simultaneously. When the course litter and sand $(>53 \mu \mathrm{m})$ 
fraction was removed from a soy field soil sample, COS production increased per gram of incubated sample (Fig. 7). This implies that the origin of the COS emissions resides in the silt and clay-associated fraction of organic matter, which has been shown to consist of plant matter that has undergone some microbial processing (Six et al., 2001, 2002). The combination of microbial activities and increased accessibility of organic matter to degradation may lead to large COS emissions from soils. While these mechanisms may explain differences between managed and non-managed soil COS exchange, we still lack a hypothesis for the difference between the small sinks in European arable soils and the temperaturedriven sources in US and Chinese arable soils.

\subsection{Comparison to field observations}

The drawdown of COS over North America has been observed from aircraft vertical profiles, appearing to scale with GPP-based uptake of COS by plants (Campbell et al., 2008). Data presented here indicate soil COS emission was maximum during high-temperature incubations, coincident with some surface temperatures observed during the North American growing season. We generated a model in Sects. 2.3 and 3.2 to calculate COS fluxes for US agricultural soils, taking these large emissions into account. Relating laboratory measurements to in situ observations has inherent problems, so we present this as a theoretical exercise investigating the possible magnitudes of soil COS exchange on broader scales.

We plotted our equation with one developed by Maseyk et al. (2014) from fluxes (Fig. 15a) and environmental parameters (Fig. 15b) recorded in situ at a wheat field in Oklahoma over the course of that study in 2012. The COS flux model developed by Kesselmeier et al. (1999) is displayed using the same input variables, assuming a constant ambient COS mixing ratios of $500 \mathrm{ppt}$ and a standard flux of $75.3 \mathrm{pmol} \mathrm{m}^{-2} \mathrm{~s}^{-1}$ (Fig. 15b). This last equation can only predict COS soil uptake and has been used to model soil COS exchange globally (Kettle et al., 2002).

Key patterns emerged from examining differences between the observations and predictions over the course of the campaign in Maseyk et al. (2014) (Fig. 15), noting first that the model presented by Kesselmeier et al. (1999) and the model presented here were not parameterized using soil from this site. The fact that there are any similarities at all between the model outputs and observations is encouraging for future modeling efforts. None of the three models captured the large emissions observed before day of year (DOY) 130 when wheat was present in the field and higher soil moisture occurred. None of the models captured the large swings from COS source to sink found during large temperature fluctuations between DOY 110 and 115. After DOY 130, the wheat senesced and was harvested, resulting in hot and dry soils. The simple model from Maseyk et al. (2014) reproduced the COS soil flux variability better under these conditions. The Kesselmeier et al. (1999) model generated some variability, but could not predict any soil COS emissions. This study's model overlapped both the uptake model's variability during wheat senescence and the high emissions predicted by Maseyk et al. (2014) after wheat harvest.

There are several explanations for the discrepancies between models and flux observations. Both this study and the Kesselmeier et al. (1999) model were based on idealized laboratory conditions, not taking into account interactions with soil COS exchange at different depths. No doubt COS is produced or consumed in all layers of soil, not just at the surface, but soil incubations were purposefully designed to avoid these issues. Additionally, there is variability in both soil moisture and temperature even over the area of the soil plot: a heterogeneous soil may experience variations in these parameters on a small scale (Entin et al., 2000). Also, soil temperature was measured at $5 \mathrm{~cm}$, generally cooler than the observed surface temperature for the site (Maseyk et al., 2014). While there was not enough variability in soil moisture and temperature to perform a similar treatment as shown in Fig. 13 for field observations, we believe the hybrid model presented here will lead to new investigations that close the gap between lab-based COS observations and COS exchange at larger scales.

\subsection{Implications for uncertainty in COS-based GPP estimates}

The main motivation of this work was to make progress towards better estimates of GPP. The drawdown of COS over the continents appears to be associated with the uptake of carbon dioxide (Campbell et al., 2008). For some of the biomes explored here, like deserts, soil COS exchange under field conditions may actually be negligible compared to plant uptake. On the other hand, recent work has suggested that soil COS fluxes in agricultural areas might be large and need to be taken into account (Billesbach et al., 2014; Maseyk et al., 2014). The model presented in this study anticipates these agricultural soil COS fluxes using commonly measured variables. With such a correction, applying the COS-GPP tracer will be more feasible to constrain GPP estimates on regional scales.

Taking COS soil fluxes into account when estimating GPP can avoid over- and underestimations of carbon fluxes presented in Table 4 and Fig. 14. Observations are still scarce: despite a plea for data from desert soils by Kettle et al. (2002), we were not able to find such a study in the literature over 10 years later. Boreal forest soil COS exchange estimates are represented by a single study performed at a single site in Sweden over the course of 2 months in 1993 (Simmons, 1999). Modeling efforts suggest large COS fluxes in the tropics (Berry et al., 2013; Suntharalingam et al., 2008) and tropical forests and savannahs are associated with $60 \%$ of global terrestrial GPP (Beer et al., 2010). However, there remains a dearth of observations in tropical latitudes. 
This magnitude of avoidable error suggests that soil fluxes are not negligible; however, the uncertainty of GPP at regional to global scales is much larger. The error introduced by large soil emissions from cropland soils to COS-GPP estimates can be avoided by characterization and correction of COS fluxes. This study's approach deconvolves the production rates seen to dominate the net COS flux in Maseyk et al. (2014) and the small uptake rates observed in sandy soils by Van Diest and Kesselmeier (2008).

\section{Conclusions}

The quantity of data in Table 4 suggests a dire need for more information about soil COS exchange. Here we presented a controlled study using soil from multiple ecosystems and cohesive theory for how to interpret observed soil COS fluxes. This study confirms that soil from many biomes exhibited small COS fluxes compared to estimated plant sinks. However, field studies must be conducted to determine the extent of the larger magnitude US agricultural soil COS exchange in order to quantify and correct for soil effects in GPP proxy models. The difference in COS flux behavior between agricultural soils investigated in the US and Europe also remains an open question.

A final complication arises from water stress: changes in soil moisture can cause the release of pulses of COS to the atmosphere (Fig. 12) while affecting photosynthesis and associated plant COS uptake. Additionally, COS exchange during freeze-thaw events will shed light on conditions that no field or laboratory study has yet determined. If the COS soil sink is indeed overwhelmingly microbial, water stresses will play an important role in their community diversity and function (Schimel et al., 2007), which may control the balance of COS over ecosystems.

Acknowledgements. The authors thank J. Kesselmeier, L. Kooijmans, and H. Chen for technical insights and manuscript feedback; D. Chadwick, J. Thom, L. Meredith, J. Chalfant, and W. Sun for sample collection; K. MacFarlane, T. Guilderson, S. Biraud, and K. Maseyk for sampling advice and data sharing; M. Zahniser and A. Kornfeld for QCL technical support; and G. Badgley, K. Caldeira, and R. Commane for data analysis suggestions. Equipment was purchased through NSF DBI grant \#1 040106. Funding for the US-WCr AmeriFlux ChEAS cluster core site was provided by the U.S. Department of Energy's Office of Science. The CFSR data were developed by NOAA's National Centers for Environmental Prediction (NCEP). The data for Fig. 1 are from NOAA's National Operational Model Archive and Distribution System (NOMADS), which is maintained at NOAA's National Climatic Data Center (NCDC). This study used the CFSRv2 hourly time series data for soil moisture (soilm1.gdas.*.grb2 files; Soil Moisture Level 1 on T382 Gaussian Grid) and soil temperature (soilt1.gdas.*.grb2 files; Soil Temperature Level 1 on T382 Gaussian Grid). The data used to generate Fig. 14 used eddy covariance data acquired by the FLUXNET community and in particular AmeriFlux (U.S. Department of Energy, Biological and Environmental Research, Terrestrial Carbon Program (DEFG02-04ER63917 and DE-FG02-04ER63911)). We acknowledge the financial support to the eddy covariance data harmonization provided by CarboEuropeIP, FAO-GTOS-TCO, iLEAPS, Max Planck Institute for Biogeochemistry, National Science Foundation, University of Tuscia, Université Laval, Environment Canada, the US Department of Energy, the database development and technical support from Berkeley Water Center, Lawrence Berkeley National Laboratory, Microsoft Research eScience, Oak Ridge National Laboratory, University of California - Berkeley, and University of Virginia. This manuscript is based upon work supported by the National Science Foundation under grant number 1433257.

Edited by: M. von Hobe

\section{References}

Anderson, R. G. and Goulden, M. L.: Relationships between climate, vegetation, and energy exchange across a montane gradient, J. Geophys. Res.-Biogeo., 116, G01026, doi:10.1029/2010JG001476, 2011.

Asaf, D., Rotenberg, E., Tatarinov, F., Dicken, U., Montzka, S. A., and Yakir, D.: Ecosystem photosynthesis inferred from measurements of carbonyl sulphide flux, Nat. Geosci., 6, 186-190, doi:10.1038/ngeo1730, 2013.

Beer, C., Reichstein, M., Tomelleri, E., Ciais, P., Jung, M., Carvalhais, N., Rödenbeck, C., Arain, M. A., Baldocchi, D., and Bonan, G. B.: Terrestrial gross carbon dioxide uptake: global distribution and covariation with climate, Science, 329, 834-838, doi:10.1126/science.1184984, 2010.

Behrendt, T., Veres, P. R., Ashuri, F., Song, G., Flanz, M., Mamtimin, B., Bruse, M., Williams, J., and Meixner, F. X.: Characterisation of NO production and consumption: new insights by an improved laboratory dynamic chamber technique, Biogeosciences, 11, 5463-5492, doi:10.5194/bg-11-5463-2014, 2014.

Berkelhammer, M., Asaf, D., Still, C., Montzka, S., Noone, D., Gupta, M., Provencal, R., Chen, H., and Yakir, D.: Constraining surface carbon fluxes using in situ measurements of carbonyl sulfide and carbon dioxide, Global Biogeochem. Cy., 28, 161-179, doi:10.1002/2013GB004644, 2014.

Berry, J., Wolf, A., Campbell, J. E., Baker, I., Blake, N., Blake, D., Denning, A. S., Kawa, S. R., Montzka, S. A., Seibt, U., Stimler, K., Yakir, D., and Zhu, Z.: A coupled model of the global cycles of carbonyl sulfide and $\mathrm{CO}_{2}$ : a possible new window on the carbon cycle, J. Geophys. Res.-Biogeo., 118, 842-852, doi:10.1002/jgrg.20068, 2013.

Billesbach, D. P., Berry, J. A., Seibt, U., Maseyk, K., Torn, M. S., Fischer, M. L., Abu-Naser, M., and Campbell, J. E.: Growing season eddy covariance measurements of carbonyl sulfide and $\mathrm{CO}_{2}$ fluxes: $\mathrm{COS}$ and $\mathrm{CO}_{2}$ relationships in Southern Great Plains winter wheat, Agr. Forest Meteorol., 184, 48-55, doi:10.1016/j.agrformet.2013.06.007, 2014.

Blonquist, J. M., Montzka, S. A., Munger, J. W., Yakir, D., Desai, A. R., Dragoni, D., Griffis, T. J., Monson, R. K., Scott, R. L., and Bowling, D. R.: The potential of carbonyl sulfide as a proxy for gross primary production at flux tower sites, J. Geophys. Res.Biogeo., 116, 1-18, doi:10.1029/2011JG001723, 2011. 
Campbell, J. E., Carmichael, G. R., Chai, T., Mena-Carrasco, M., Tang, Y., Blake, D. R., Blake, N. J., Vay, S. A., Collatz, G. J., Baker, I., Berry, J. A., Montzka, S. A., Sweeney, C., Schnoor, J. L., and Stanier, C. O.: Photosynthetic control of atmospheric carbonyl sulfide during the growing season, Science, 322, 1085-1088, doi:10.1126/science.1164015, 2008.

Campbell, J. E., Whelan, M. E., Seibt, U., Smith, S. J., Berry, J. A., and Hilton, T. W.: Atmospheric carbonyl sulfide sources from anthropogenic activity: implications for carbon cycle constraints, Geophys. Res. Lett., 42, 3004-3010, doi:10.1002/2015GL063445, 2015.

Castro, M. S. and Galloway, J. N.: A comparison of sulfur-free and ambient air enclosure techniques for measuring the exchange of reduced sulfur gases between soils and the atmosphere, J. Geophys. Res., 96, 15427-15437, doi:10.1029/91JD01399, 1991.

Commane, R., Herndon, S. C., Zahniser, M. S., Lerner, B. M., McManus, J. B., Munger, J. W., Nelson, D. D., and Wofsy, S. C.: Carbonyl sulfide in the planetary boundary layer: coastal and continental influences, J. Geophys. Res.-Atmos., 118, 80018009, 2013.

Conrad, R.: Compensation concentration as critical variable for regulating the flux of trace gases between soil and atmosphere, Biogeochemistry, 27, 155-170, doi:, 1994.

Conrad, R.: Soil microorganisms as controllers of atmospheric trace gases $\left(\mathrm{H}_{2}, \mathrm{CO}, \mathrm{CH}_{4}, \mathrm{OCS}, \mathrm{N}_{2} \mathrm{O}\right.$, and $\left.\mathrm{NO}\right)$, Microbiol. Rev., 60, 609-640, 1996.

Cook, B. D., Davis, K. J., Wang, W., Desai, A., Berger, B. W., Teclaw, R. M., Martin, J. G., Bolstad, P. V., Bakwin, P. S., Yi, C., and Heilman, W.: Carbon exchange and venting anomalies in an upland deciduous forest in northern Wisconsin, USA, Agr. Forest Meteorol., 126, 271-295, doi:10.1016/j.agrformet.2004.06.008, 2004.

De Mello, W. Z. and Hines, M. E.: Application of static and dynamic enclosures for determining dimethyl sulfide and carbonyl sulfide exchange in Sphagnum peatlands: implications for the magnitude and direction of flux, J. Geophys. Res., 99, 1460114607, 1994.

Desai, A. R., Richardson, A. D., Moffat, A. M., Kattge, J., Hollinger, D. Y., Barr, A., Falge, E., Noormets, A., Papale, D., Reichstein, M., and Stauch, V. J.: Cross-site evaluation of eddy covariance GPP and RE decomposition techniques, Agr. Forest Meteorol., 148, 821-838, doi:10.1016/j.agrformet.2007.11.012, 2008.

Entin, J. K., Robock, A., Vinnikov, K. Y., Hollinger, S. E., Liu, S., and Namkhai, A.: Temporal and spatial scales of observed soil moisture variations in the extratropics, J. Geophys. Res.-Atmos., 105, 11865-11877, doi:10.1029/2000JD900051, 2000.

Fried, A., Klinger, L. F. and Erickson, D. J.: Atmospheric carbonyl sulfide exchange in bog microcosms, Geophys. Res. Lett., 20, 129-132, doi:199310.1029/93GL00062, 1993.

Geng, C. and Mu, Y.: Carbonyl sulfide and dimethyl sulfide exchange between trees and the atmosphere, Atmos. Environ., 40, 1373-1383, doi:10.1016/j.atmosenv.2005.10.023, 2006.

Griffiths, B. S. and Philippot, L.: Insights into the resistance and resilience of the soil microbial community, FEMS Microbiol. Rev., 37, 112-129, doi:10.1111/j.1574-6976.2012.00343.x, 2013.

Kato, H., Saito, M., Nagahata, Y. and Katayama, Y.: Degradation of ambient carbonyl sulfide by Mycobacterium spp. in soil, Microbiology, 154, 249-255, doi:10.1099/mic.0.2007/011213-0, 2008.
Kesselmeier, J., Teusch, N., and Kuhn, U.: Controlling variables for the uptake of atmospheric carbonyl sulfide by soil, J. Geophys Res., 104, 11577-11584, doi:10.1029/1999JD900090, 1999.

Kettle, A. J., Kuhn, U., von Hobe, M., Kesselmeier, J., and Andreae, M. O.: Global budget of atmospheric carbonyl sulfide: temporal and spatial variations of the dominant sources and sinks, J. Geophys. Res.-Atmos., 107, 1-16, doi:10.1029/2002JD002187, 2002.

Kooijmans, L. M. J., Uitslag, N. A. M., Zahniser, M. S., Nelson, D. D., Montzka, S. A., and Chen, H.: Continuous and high precision atmospheric concentration measurements of $\mathrm{COS}, \mathrm{CO}_{2}, \mathrm{CO}$ and $\mathrm{H}_{2} \mathrm{O}$ using a quantum cascade laser spectrometer (QCLS), Atmos. Meas. Tech. Discuss., doi:10.5194/amt-2016-50, in review, 2016.

Kuhn, U., Ammann, C., Wolf, A., Meixner, F. X., Andreae, M. O., and Kesselmeier, J.: Carbonyl sulfide exchange on an ecosystem scale: soil represents a dominant sink for atmospheric COS, Atmos. Environ., 33, 995-1008, 1999.

Liu, J., Geng, C., Mu, Y., Zhang, Y., Xu, Z., and Wu, H.: Exchange of carbonyl sulfide (COS) between the atmosphere and various soils in China, Biogeosciences, 7, 753-762, doi:10.5194/bg-7753-2010, 2010.

Manzoni, S., Schimel, J. P., and Porporato, A.: Responses of soil microbial communities to water stress: results from a meta-analysis, Ecology, 93, 930-938, doi:10.1890/11-0026.1, 2011.

Maseyk, K., Berry, J. A., Billesbach, D., Campbell, J. E., Torn, M. S., Zahniser, M., and Seibt, U.: Sources and sinks of carbonyl sulfide in an agricultural field in the Southern Great Plains, P. Natl. Acad. Sci. USA, 111, 9064-9069, doi:10.1073/pnas.1319132111, 2014

Melillo, J. M. and Steudler, P. A.: The effect of nitrogen fertilization on the $\mathrm{COS}$ and $\left(\mathrm{CS}_{2}\right)$ emissions from temperature forest soils, J. Atmos. Chem., 9, 411-417, 1989.

Meyers, T. and Hollinger, S. E.: An assessment of storage terms in the surface energy balance of maize and soybean, Agr. Forest Meteorol., 125, 105-115, doi:10.1016/j.agrformet.2004.03.001, 2004.

Montzka, S. A., Calvert, P., Hall, B. D., Elkins, J. W., Conway, T. J., Tans, P. P., and Sweeney, C.: On the global distribution, seasonality, and budget of atmospheric carbonyl sulfide (COS) and some similarities to $\mathrm{CO}_{2}$, J. Geophys. Res.-Atmos., 112, D09302, doi:10.1029/2006JD007665, 2007.

Ogée, J., Sauze, J., Kesselmeier, J., Genty, B., Van Diest, H., Launois, T., and Wingate, L.: A new mechanistic framework to predict OCS fluxes from soils, Biogeosciences Discuss., 12, 15687-15736, doi:10.5194/bgd-12-15687-2015, 2015.

Protoschill-Krebs, G. and Kesselmeier, J.: Enzymatic pathways for the consumption of carbonyl sulphide (COS) by higher plants, Bot. Acta, 105, 206-212, 1992.

Protoschill-Krebs, G., Wilhelm, C., and Kesselmeier, J.: Consumption of carbonyl sulphide (COS) by higher plant carbonic anhydrase (CA), Atmos. Environ., 30, 3151-3156, doi:10.1016/13522310(96)00026-X, 1996.

Reichstein, M., Falge, E., Baldocchi, D., Papale, D., Aubinet, M., Berbigier, P., Bernhofer, C., Buchmann, N., Gilmanov, T., Granier, A., Grünwald, T., Havránková, K., Ilvesniemi, H., Janous, D., Knohl, A., Laurila, T., Lohila, A., Loustau, D., Matteucci, G., Meyers, T., Miglietta, F., Ourcival, J.-M., Pumpanen, J., Rambal, S., Rotenberg, E., Sanz, M., Tenhunen, J., 
Seufert, G., Vaccari, F., Vesala, T., Yakir, D., and Valentini, R.: On the separation of net ecosystem exchange into assimilation and ecosystem respiration: review and improved algorithm, Glob. Change Biol., 11, 1424-1439, doi:10.1111/j.13652486.2005.001002.x, 2005.

Saha, S., Moorthi, S., Pan, H.-L., Wu, X., Wang, J., Nadiga, S., Tripp, P., Kistler, R., Woollen, J., Behringer, D., Liu, H., Stokes, D., Grumbine, R., Gayno, G., Wang, J., Hou, Y.-T., Chuang, H.-Y., Juang, H.-M. H., Sela, J., Iredell, M., Treadon, R., Kleist, D., Van Delst, P., Keyser, D., Derber, J., Ek, M., Meng, J., Wei, H., Yang, R., Lord, S., Van Den Dool, H., Kumar, A., Wang, W., Long, C., Chelliah, M., Xue, Y., Huang, B., Schemm, J.-K., Ebisuzaki, W., Lin, R., Xie, P., Chen, M., Zhou, S., Higgins, W., Zou, C.-Z., Liu, Q., Chen, Y., Han, Y., Cucurull, L., Reynolds, R. W., Rutledge, G., and Goldberg, M.: The NCEP climate forecast system reanalysis, B. Am. Meteorol. Soc., 91, 1015-1057, doi:10.1175/2010BAMS3001.1, 2010.

Sandoval-Soto, L., Stanimirov, M., von Hobe, M., Schmitt, V., Valdes, J., Wild, A., and Kesselmeier, J.: Global uptake of carbonyl sulfide (COS) by terrestrial vegetation: Estimates corrected by deposition velocities normalized to the uptake of carbon dioxide $\left(\mathrm{CO}_{2}\right)$, Biogeosciences, 2, 125-132, doi:10.5194/bg-2-1252005, 2005.

Schenk, S., Kesselmeier, J., and Anders, E.: How does the exchange of one oxygen atom with sulfur affect the catalytic cycle of carbonic anhydrase?, Chem.-Eur. J., 10, 3091-3105, doi:10.1002/chem.200305754, 2004.

Schimel, J., Balser, T. C., and Wallenstein, M.: Microbial stressresponse physiology and its implications for ecosystem function, Ecology, 88, 1386-1394, doi:10.1890/06-0219, 2007.

Seibt, U., Kesselmeier, J., Sandoval-Soto, L., Kuhn, U., and Berry, J. A.: A kinetic analysis of leaf uptake of COS and its relation to transpiration, photosynthesis and carbon isotope fractionation, Biogeosciences, 7, 333-341, doi:10.5194/bg-7-333-2010, 2010.

Simmons, J. S.: Consumption of atmospheric carbonyl sulfide by coniferous boreal forest soils, J. Geophys. Res., 104, 1156911576, doi:10.1029/1999JD900149, 1999.

Six, J., Guggenberger, G., Paustian, K., Haumaier, L., Elliott, E. T., and Zech, W.: Sources and composition of soil organic matter fractions between and within soil aggregates, Eur. J. Soil Sci., 52, 607-618, doi:10.1046/j.1365-2389.2001.00406.x, 2001.

Six, J., Conant, R. T., Paul, E. A., and Paustian, K.: Stabilization mechanisms of soil organic matter: implications for C-saturation of soils, Plant Soil, 241, 155-176, doi:10.1023/A:1016125726789, 2002.

Sollins, P., Homann, P., and Caldwell, B. A.: Stabilization and destabilization of soil organic matter: mechanisms and controls, Geoderma, 74, 65-105, doi:10.1016/S0016-7061(96)00036-5, 1996.

Steinbacher, M., Bingemer, H. G. and Schmidt, U.: Measurements of the exchange of carbonyl sulfide (OCS) and carbon disulfide (CS2) between soil and atmosphere in a spruce forest in central Germany, Atmos. Environ., 38, 6043-6052, 2004.
Stimler, K., Montzka, S. A., Berry, J. A., Rudich, Y., and Yakir, D.: Relationships between carbonyl sulfide (COS) and $\mathrm{CO}_{2}$ during leaf gas exchange, New Phytol., 186, 869-878, doi:10.1111/j.1469-8137.2010.03218.x, 2010.

Stimler, K., Berry, J. A., Montzka, S. A., and Yakir, D.: Association between Carbonyl Sulfide Uptake and $18 \Delta$ during Gas Exchange in C3 and C4 Leaves, Plant Physiol., 157, 509-517, doi:10.1104/pp.111.176578, 2011.

Sun, W., Maseyk, K., Lett, C., and Seibt, U.: A soil diffusionreaction model for surface COS flux: COSSM v1, Geosci. Model Dev., 8, 3055-3070, doi:10.5194/gmd-8-3055-2015, 2015.

Suntharalingam, P., Kettle, A. J., Montzka, S. M., and Jacob, D. J.: Global 3-D model analysis of the seasonal cycle of atmospheric carbonyl sulfide: implications for terrestrial vegetation uptake, Geophys. Res. Lett., 35, L19801, doi:10.1029/2008GL034332, 2008.

Van Diest, H. and Kesselmeier, J.: Soil atmosphere exchange of carbonyl sulfide (COS) regulated by diffusivity depending on waterfilled pore space, Biogeosciences, 5, 475-483, doi:10.5194/bg-5475-2008, 2008.

Whelan, M. and Rhew, R.: Carbonyl sulfide produced by abiotic thermal and photo-degradation of soil organic matter from wheat field substrate, J. Geophys. Res.-Biogeo., 120, 54-62, doi:10.1002/2014JG002661, 2015.

Whelan, M. E., Min, D.-H., and Rhew, R. C.: Salt marshes as a source of atmospheric carbonyl sulfide, Atmos. Environ., 73, 131-137, doi:10.1016/j.atmosenv.2013.02.048, 2013.

White, M. L., Zhou, Y., Russo, R. S., Mao, H., Talbot, R., Varner, R. K., and Sive, B. C.: Carbonyl sulfide exchange in a temperate loblolly pine forest grown under ambient and elevated $\mathrm{CO}_{2}$, Atmos. Chem. Phys., 10, 547-561, doi:10.5194/acp-10-547-2010, 2010.

Wingate, L., Ogée, J., Cuntz, M., Genty, B., Reiter, I., Seibt, U., Yakir, D., Maseyk, K., Pendall, E. G., Barbour, M. M., Mortazavi, B., Burlett, R., Peylin, P., Miller, J., Mencuccini, M., Shim, J. H., Hunt, J. and Grace, J.: The impact of soil microorganisms on the global budget of $\delta 18 \mathrm{O}$ in atmospheric $\mathrm{CO}_{2}$, P. Natl. Acad. Sci., 106, 22411-22415, doi:10.1073/pnas.0905210106, 2009.

Wofsy, S. C.: Where has all the carbon gone?, Science, 292, 22612263, doi:10.1126/science.1061077, 2001.

Yi, Z., Wang, X., Sheng, G., Zhang, D., Zhou, G. and Fu, J.: Soil uptake of carbonyl sulfide in subtropical forests with different successional stages in south China, J. Geophys. Res., 112, D08302, doi:10.1029/2006JD008048, 2007. 